\title{
Collagen transport and related pathways in Osteogenesis Imperfecta
}

\author{
Lauria Claeys $^{1}$ (1) Silvia Storoni ${ }^{2} \cdot$ Marelise Eekhoff $^{2} \cdot$ Mariet Elting $^{1} \cdot$ Lisanne Wisse $^{1} \cdot$ Gerard Pals $^{1}$. \\ Nathalie Bravenboer ${ }^{3} \cdot$ Alessandra Maugeri $^{1} \cdot$ Dimitra Micha $^{1}$
}

Received: 9 April 2021 / Accepted: 8 June 2021 / Published online: 24 June 2021

(c) The Author(s) 2021

\begin{abstract}
Osteogenesis Imperfecta (OI) comprises a heterogeneous group of patients who share bone fragility and deformities as the main characteristics, albeit with different degrees of severity. Phenotypic variation also exists in other connective tissue aspects of the disease, complicating disease classification and disease course prediction. Although collagen type I defects are long established as the primary cause of the bone pathology, we are still far from comprehending the complete mechanism. In the last years, the advent of next generation sequencing has triggered the discovery of many new genetic causes for OI, helping to draw its molecular landscape. It has become clear that, in addition to collagen type I genes, OI can be caused by multiple proteins connected to different parts of collagen biosynthesis. The production of collagen entails a complex process, starting from the production of the collagen I $\alpha 1$ and collagen I $\alpha 2$ chains in the endoplasmic reticulum, during and after which procollagen is subjected to a plethora of posttranslational modifications by chaperones. After reaching the Golgi organelle, procollagen is destined to the extracellular matrix where it forms collagen fibrils. Recently discovered mutations in components of the retrograde transport of chaperones highlight its emerging role as critical contributor of OI development. This review offers an overview of collagen regulation in the context of recent gene discoveries, emphasizing the significance of transport disruptions in the OI mechanism. We aim to motivate exploration of skeletal fragility in OI from the perspective of these pathways to identify regulatory points which can hint to therapeutic targets.
\end{abstract}

\section{Osteogenesis Imperfecta: are we ready to classify it?}

Osteogenesis Imperfecta, or brittle bone syndrome, is a rare genetic connective tissue disease. It is characterized by altered microarchitecture of the bone, which leads to fragility (Glorieux 2001). In the more severe cases, patients also manifest a variable degree of skeletal dysplasia and short stature. Patients may also be affected by extraskeletal features such as dentinogenesis imperfecta, hearing loss and blue sclera (Van Dijk et al. 2010). Cardiac valvulopathies

Dimitra Micha

d.micha@amsterdamumc.nl

1 Department of Clinical Genetics, Amsterdam UMC, Amsterdam Movement Sciences, Vrije Universiteit Amsterdam, Amsterdam, The Netherlands

2 Department of Internal Medicine Section Endocrinology, Amsterdam UMC, Amsterdam Movement Sciences, Vrije Universiteit Amsterdam, Amsterdam, The Netherlands

3 Department of Clinical Chemistry, Amsterdam /UMC, Amsterdam Movement Sciences, Vrije Universiteit Amsterdam, Amsterdam, The Netherlands and aortic dilatation are one of the most common cardiovascular aspects of OI (Ashournia et al. 2015); altered diastolic function is also reported which may also predispose OI patients to higher risk for cardiovascular disease (Migliaccio et al. 2009; Radunovic and Steine 2015). The prevalence of OI is approximately 1 in 15-20,000, qualifying as one of the most prevalent inherited skeletal disorders. Defects in collagen type I are central in the systemic pathology of the disease.

OI is a phenotypically and molecularly heterogeneous group of disorders (Forlino and Marini 2016). Because of this variability, many researchers have attempted to develop models for its classification in an effort to aid its efficient communication and understanding. The most commonly used classification is the "Sillence classification", established by David Sillence (Sillence et al. 1979; Van Dijk et al. 2010). This classification initially divided the disease in four different types based on the clinical findings and the mode of inheritance. OI type I is phenotypically classified as the mildest type of OI; this patient group experiences a variable number of bone fractures and usually blue sclerae (Van Dijk and Sillence 2014). This is in great contrast to the 
most severe phenotype, classified as OI type II, characterized by prenatal onset of multiple fractures and deformity of the long bones and the ribs, resulting in perinatal lethality. In addition, OI type II is subdivided in three classes (A, B and C) based on differences in radiographic features (Gajko-Galicka 2002). Type III is the most severe adult form of OI, with patients suffering from severe gradual deformity of the long bones and/or spine (Gajko-Galicka 2002). The patient group diagnosed with type IV OI is the most phenotypically diverse, from mild to severe. Similar to the other types, the patients have fragile bones with and without progressive deformities of the long bones and spine (Sillence et al. 1979).

\section{Gene discovery in Ol classification}

To facilitate the discovery of many new genes associated with OI in the last two decades, this classification has been expanded to approximately 20 different types (Bacon and Crowley 2018; Etich et al. 2020b; Hayat et al. 2020). This genetic classification is based on the causative gene, rather than the clinical presentation. However, the ongoing emerging of new genetic causes made clear that $\mathrm{OI}$ is a more complex disorder than originally thought, of which the genotype-phenotype correlation is incompletely understood. Genetic causes of OI present a lot of clinical overlap (Table 1) so the genetic classification does not facilitate efficient communication of the disease, and it does not keep up with gene discovery. For this reason, in 2010 experts proposed to simplify the classification by returning to the four clinical types described by Sillence, with the addition of the clinically distinct type $\mathrm{V}$, which includes moderately affected patients and which is uniquely characterized by hyperplastic callus formation and interosseous membrane ossification; as opposed to the genetic variability of the other types, type $\mathrm{V}$ is only caused by one specific mutation in the gene interferon induced transmembrane protein 5, IFITM5 (Van Dijk et al. 2010). According to this classification, most causative genes lead to moderate-severe phenotypes (Table 1) (Van Dijk and Sillence 2014). It is notable that the five Sillence types are based on overall clinical severity largely depending on skeletal features. There exists incomplete evidence about the correlation between the type of OI and the other systemic features of OI (Lindahl et al. 2015; Zhytnik et al. 2019).

Although, based on the current state of knowledge it is still preferable to define OI types clinically, inventorying of the molecular diagnosis complements the clinical evaluation and is also paramount for the expansion of our mechanistic comprehension of the disease. Mutations in several OIcausing genes are divided into two groups, the first group includes mutations leading to haploinsufficiency/quantitative defects in collagen type I, whereas, mutations in the other group lead to structural/qualitative defects (Byers et al. 1991). The state of haploinsufficiency usually arises from indels, splice site and frameshift mutations in the collagen type I genes leading to no or unstable mRNA. Although there are exceptions, a general trend exists for haploinsufficiency leading to the milder type I and IV types. Structural alterations of the type I collagen can be caused by mutations in collagen type I genes (dominant negative effect) or can be the result of the defective modification of collagen chains by mutations in the collagen-processing chaperones such as CRTAP, P3H1 and CYPB (van Dijk et al. 2009a, b). Although the latter mostly correlates with moderate-severe OI (Table 1), the phenotypic effect of structural mutations in collagen genes, such as glycine substitutions, varies depending on their location and nature as well as on the chain type (Raghunath et al. 1994; Xiao et al. 2011).

\section{Collagen type $\mathrm{I}$ is central to the Osteogenesis Imperfecta pathology}

The genetic background of OI is heterogeneous and currently consists of around 20 genes which are implicated in the regulation of collagen type I or other aspects of bone biology (Etich et al. 2020a). Approximately 85\% of patients with OI possess an autosomal dominant mutation in COL1A1 or COL1A2 genes. They encode the $\alpha 1$ (I) and $\alpha 2$ (I) chains of type I collagen, which is the most abundant protein in bone, skin and tendon extracellular matrices (Forlino and Marini 2016). It can also be found in arteries and the heart ventricles, which accounts for the cardiovascular problems. The remaining $15 \%$ of the patients have mutations in genes coding for proteins needed for the transcription [CREB3L1 (cAMP responsive element binding protein 3-like 1), MBTPS2 (membrane-bound transcription factor peptidase site 2)], synthesis [TMEM38B (Trimeric intracellular cation channel type B)], posttranslational modification [LEPRE1 (Leucine Proline-Enriched Proteoglycan (Leprecan) 1), CRTAP (Cartilage-Associated Protein), PPIB (Peptidyl-prolyl cis-trans isomerase B), PLOD2 (Procollagen-Lysine, 2Oxoglutarate 5-Dioxygenase 2)] and chaperone proteins [SERPINH1 (Serpin Family H Member 1) and FKBP10 (FKBP Prolyl Isomerase 10)], retrograde transport [KDELR2 (KDEL Endoplasmic Reticulum Protein Retention Receptor 2) and NBAS (NBAS Subunit Of NRZ Tethering Complex)] and extracellular processing [BMPI (Bone Morphogenetic Protein 1)] of procollagen or for bone synthesis, development or structure both with regard to bone cell function and differentiation as well as extracellular matrix (ECM) composition [SERPINF 1 (Serpin Family F Member 1), IFITM5 (Interferon-Induced Transmembrane Protein 5), SPARC (Secreted Protein Acidic And Cysteine-Rich), TENT5A (Terminal Nucleotidyltransferase 5A), PLS3 (Plastin 3), WNT1 
Table 1 Sillence Classification expanded to OI type V and atypical OI associated with phenotypes and inheritance pattern of OI causative genes up to date (Van Dijk and Sillence 2014)

\begin{tabular}{|c|c|c|c|c|c|}
\hline Sillence type & Clinical severity & Mutated gene(s) & Protein name & Mode of inh. ${ }^{\mathrm{a}}$ & Pathway \\
\hline \multirow[t]{2}{*}{ I } & \multirow[t]{2}{*}{ Mild, non deforming } & COL1A1/2 (Sillence et al. 1979) & COL1A $1 / 2$ & $\mathrm{AD}$ & \\
\hline & & CREB3L1 (Keller et al. 2018) & OASIS & AR & ER stress response \\
\hline \multirow[t]{6}{*}{ II (A, B and C) } & \multirow[t]{6}{*}{ Perinatal lethal } & COL1A1/2 (Sillence et al. 1979) & COL1A1/2 & $\mathrm{AD}$ & \\
\hline & & CREB3L1 (Symoens et al. 2013), & OASIS & AR & ER stress response \\
\hline & & CRTAP (Morello et al. 2006), & CRTAP & & Posttranslational mod \\
\hline & & KDELR2 (van Dijk et al. 2020), & KDELR2 & & Retrograde vesicle transp \\
\hline & & $\begin{array}{l}\text { LEPRE1 (Cabral et al. 2007; } \\
\text { Moul et al. 2013), }\end{array}$ & P3H1 & & Posttranslational mod \\
\hline & & $P P I B$ (van Dijk et al. 2009a, b) & CYPB & & Posttranslational mod \\
\hline \multirow[t]{19}{*}{ III } & \multirow[t]{19}{*}{ Progressively deforming, severe } & $\begin{array}{l}\text { BMP1 (Martínez-Glez et al. } \\
\text { 2012), }\end{array}$ & BMP1 & AR & Extracellular processing \\
\hline & & COL1A1/2 (Sillence et al. 1979) & COL1A1/2 & $\mathrm{AD}$ & \\
\hline & & CCDC134 (Dubail et al. 2020), & CCDC134 & $\mathrm{AR}$ & Regulation of MAPK \\
\hline & & CREB3L1 (Keller et al. 2018), & OASIS & & ER stress response \\
\hline & & CRTAP (Baldridge et al. 2008), & CRTAP & & Posttranslational mod \\
\hline & & IFITM5 (Farber et al. 2014), & IFITM5 & & Matrix mineralization \\
\hline & & FAM46A (Doyard et al. 2018), & TENT5A & & Unknown \\
\hline & & FKBP10 (Alanay et al. 2010), & FKBP65 & & Posttranslational mod \\
\hline & & KDELR2 (van Dijk et al. 2020), & KDELR2 & & Retrograde vesicle transp \\
\hline & & LEPRE1 (Baldridge et al. 2008), & P3H1 & & Posttranslational mod \\
\hline & & MBTPS2 (Lindert et al. 2016), & $\mathrm{S} 2 \mathrm{P}$ & XL & ER stress response \\
\hline & & MESD (Moosa et al. 2019), & MESD & $\mathrm{AR}$ & WNT signaling pathway \\
\hline & & PLOD2 (Zhou et al. 2014), & LH2 & & Posttranslational mod \\
\hline & & PPIB (van Dijk et al. 2009a, b), & CYPB & & Posttranslational mod \\
\hline & & SERPINF1 (Becker et al. 2011), & PEDF & & Matrix mineralization \\
\hline & & $\begin{array}{l}\text { SERPINH1 (Christiansen et al. } \\
\text { 2010), }\end{array}$ & HSP47 & & Posttranslational mod \\
\hline & & SP7 (Fiscaletti et al. 2018), & OSX & & Bone cell diff. and sign \\
\hline & & $\begin{array}{l}\text { TMEM38B (Volodarsky et al. } \\
\text { 2013), }\end{array}$ & TRIC-B & & $\begin{array}{l}\text { Posttranslational mod/ } \\
\mathrm{Ca}^{2+} \text { homeostasis }\end{array}$ \\
\hline & & WNT1 (Pyott et al. 2013) & WNT1 & & Bone cell diff. and sign \\
\hline \multirow[t]{6}{*}{ IV } & \multirow{6}{*}{$\begin{array}{l}\text { Moderately to severe deforming, } \\
\text { variable }\end{array}$} & COL1A1/2 (Sillence et al. 1979) & COL1A $1 / 2$ & $\mathrm{AD}$ & \\
\hline & & PLS3 (van Dijk et al. 2013) & PLS3 & XL & Actin-bundling protein \\
\hline & & PPIB (Barnes et al. 2010), & CYPB & AR & Posttranslational mod \\
\hline & & SP7 (Lapunzina et al. 2010), & OSX & & Bone cell diff. and sign \\
\hline & & $\begin{array}{l}\text { SPARC (Mendoza-Londono et al. } \\
\text { 2015), }\end{array}$ & ON & & Extracellular matrix \\
\hline & & WNT1 (Fahiminiya et al. 2013) & WNT1 & & Bone cell diff. and sign \\
\hline V & $\begin{array}{l}\text { Moderately deforming with } \\
\text { calcification in interosseous } \\
\text { membranes }\end{array}$ & IFITM5 (Corradi et al. 2015) & IFITM5 & $\mathrm{AD}$ & Matrix mineralization \\
\hline Atypical OI & & $\begin{array}{l}\text { NBAS (Balasubramanian et al. } \\
\text { 2017) }\end{array}$ & NBAS & $\mathrm{AD}$ & Retrograde transport \\
\hline
\end{tabular}

${ }^{\mathrm{a}}$ Autosomal dominant (AD), autosomal recessive (AR) and recessive X-linked (XL)

(Wnt Family Member 1), MESD (Mesoderm Development LRP Chaperone), SP7 (Sp7 Transcription Factor), CCDC134 (Coiled-Coil Domain-Containing 134)]. Mutations in these genes are mostly autosomal recessive; an exception to this are mutations in IFITM5 (autosomal dominant), PLS3 and
MBTPS2 (recessive X-linked) (Hanagata 2016). Based on this, OI has been defined as a collagen-related disorder, although the involvement in collagen regulation has not been sufficiently demonstrated for all described genetic causes, for which we rely on future studies (Forlino and Marini 2016). 
To this end, it is essential to investigate collagen in the bone tissue when abnormalities are not found in fibroblasts, which have been commonly used for these studies, although this is not always feasible. This is owing to the fact that patients are usually reluctant to undergo a bone biopsy unless it is part of a planned surgery (Murakami et al. 2011; van Dijk et al. 2012).

Collagen type I belongs to a large and diverse family of collagens that are present throughout the whole body. Collagens are characterized by a triple helix of $(\alpha)$ polypeptide chains; they can be homotrimeric or heterotrimeric. This means that they are composed of three identical alpha chains (e.g. collagen type III) or alpha chains encoded by different genes (e.g. collagen type I encoded by COL1AI and COL1A2) (Mienaltowski and Birk 2014). The amino acid triple helical domain of the collagen type I chain consists of 338 uninterrupted tripeptide units with the sequence of Gly $-X-Y$. The $X$ and $Y$ are often proline and hydroxyproline and exclude cysteine and tryptophan (Byers et al. 1991; Gelse et al. 2003). The triple helix is formed around a central axis, starting from its carboxyl-terminal globular end towards the amino-terminus with a pitch of three amino acids per turn (Byers et al. 1991; Gelse et al. 2003). The glycine residues in every third position, which are positioned centrally in the triple helix, are essential for the correct folding of the triple helix, because glycine is the smallest amino acid and the only one that fits inside the triple helix. Due to this, point mutations, such as glycine substitutions, towards the carboxyl-terminal end of the $\alpha 1$ (I) chain lead to more severe phenotypic consequences compared to equivalent mutations closer to the amino-terminus (Byers et al. 1991). This is attributed to the exposure of collagen to excessive posttranslational modification, such as hydroxylation and glycosylation, which takes place as a result of delayed triple helix folding, the extent of which depends on the position of the mutation in relation to the carboxyl-terminus (Byers et al. 1991; Engel and Prockop 1991).

Given that collagen type I is the most abundant collagen in the bone tissue, study of its regulation has been the center of OI research. Type I collagen is synthesized as procollagen which is transported from the ER to the Golgi and subsequently to the extracellular space where the mature type I collagen assembles spontaneously into staggered fibril-arrays with diameters between 25 and $400 \mathrm{~nm}$ (Gelse et al. 2003; Mienaltowski and Birk 2014). An overview of the collagen biosynthesis, with focus on the proteins connected to OI, can be seen in Fig. 1.

The aim of this review is to shed light on the transport regulation of collagen in OI from the perspective of gene discovery, by summarizing the critical points in this process from which dysregulation can lead to bone fragility. The reader is specifically guided through the modification of collagen in the endoplasmic reticulum (ER) where the contribution of chaperones to this process is explained. The vesicle transport of collagen from the ER to the Golgi is then described by emphasizing how it is facilitated considering the limitations posed by its large molecular size (anterograde transport). An important part of the review are the latest developments on the retrograde transport of chaperones which is appearing as a new mechanism in OI. Next, we cover the current state of knowledge on the extracellular processing of collagen by which it adopts a competent state for fibrillogenesis. The spectrum of skeletal disease presentation is also described as a result of mutations in components of these pathways. Finally, the implications of these findings on collagen transport are related to issues of disease classification and therapeutic prospects.

\section{ER posttranslational modification}

During translation, procollagen type I is placed in the lumen of the ER membrane where many proteins are involved in its posttranslational modification before, during and after triple helix formation which is a key requirement for its correct assembly. Some of those proteins assist for example with the C-terminal propeptide folding and stabilization (BiP, GPR94, Calnexin and PDI) (Lamande and Bateman 1999), while other proteins help with the formation of the triple helix itself (LH1,LH3 and the LH2-FKBP65 complex) (Eyre and Weis 2013; Lim et al. 2017) and others help with the stabilization of the triple helix (P3H1-CRTAP-CYPB complex and HSP47) (Duran et al. 2015; Eyre and Weis 2013; Lim et al. 2017).

Protein disulphide isomerase (PDI) catalyzes the formation of intrachain disulphide bonds in the non-collagenous $\mathrm{C}$ - and N-propeptide domains which helps to stabilize the procollagen trimers. Interchain disulphide bonds promote the association of the collagen chains at the $\mathrm{C}$-terminus which is essential for their correct alignment and triple helix formation (Boudko et al. 2012; Koivu and Myllylä 1987). The importance of this step is shown by OI C-propeptide mutations where collagen is subjected to degradation (Lamandé et al. 1995). This is accompanied by the upregulation of binding immunoglobin protein $(\mathrm{BiP})$ and glucose-regulated protein 94 (GRP94) molecular chaperones, which together with Calnexin, contribute to C-propeptide folding (Chessler and Byers 1993).

\section{Proline hydroxylation}

PDI also serves as a subunit for the enzyme prolyl 4-hydroxylase $(\mathrm{P} 4 \mathrm{H})$, the latter of which hydroxylates triple helix prolines. This is essential for the formation of the procollagen triple helix and determines its stability which is evident by the correlation of its hydroxylation level with thermal 

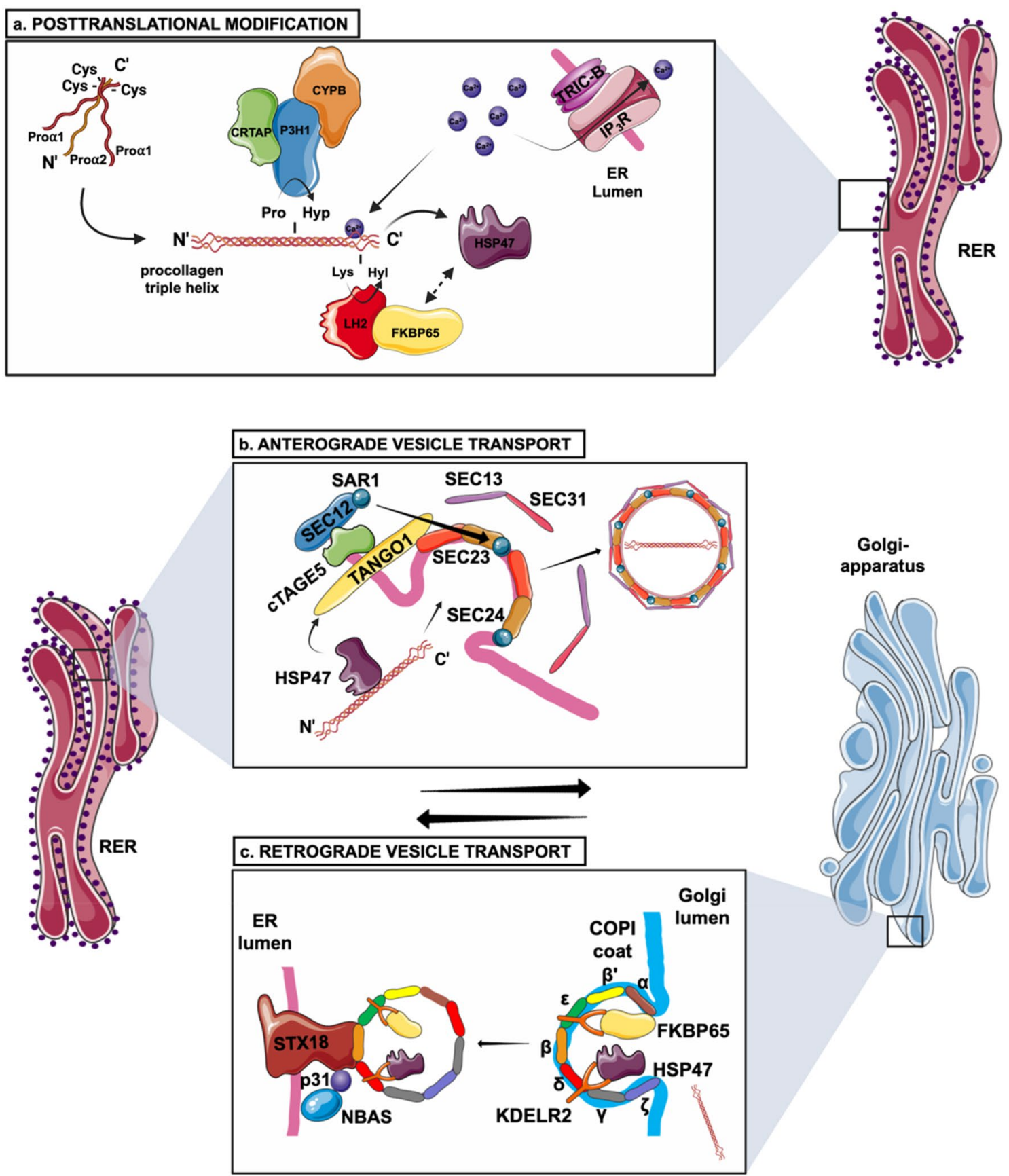

Fig. 1 Biosynthesis pathway of collagen type I. a Folding and posttranslational modification of the COL $1 \alpha 1$ and $\operatorname{COL} 1 \alpha 2$ chains and of the procollagen triple helix takes place in the RER (rough endoplasmic reticulum). These modifications are performed by the CRTAP-P3H3-CYPB and FKBP65-LH2 complexes, turning proline to hydroxyproline and lysine to hydroxylysine respectively. HSP47 is a chaperone protein which assists in the stabilization of the triple helix and its transportation through the ER. The whole process of biosynthesis of type I collagen is calcium-regulated. TRIC-B is one of the channels regulating ER $\mathrm{Ca}^{2+}$ flow via $\mathrm{IP}_{3} \mathrm{R}$ channel. $\mathrm{Ca}^{2+}$ also stabilizes the process of collagen trimerization and foldings. $\mathbf{b}$ Anterograde transport of the procollagen triple helix from the ER to the Golgi apparatus via COPII-mediated vesicle transport. Many proteins are involved in the formation of the COPII vesicle such as the SEC23/24 dimer (inner coat), the SEC13/31 dimer (outer coat),
SEC12, SAR1, TANGO1 and cTAGE5. TANGO1 and HSP47 facilitate the entering of procollagen in the forming vesicle. SEC12 and in turn SAR1 recruit SEC23/24 dimers to form the inner coat. $\mathbf{c}$ Retrograde transport of ER proteins via COPI ( $\alpha$-COP, $\beta$ '-COP, $\varepsilon$-COP, $\beta$-COP, $\delta$-COP, $\gamma$-COP and $\zeta$-COP) -mediated vesicle transport. FKBP65 and HSP47 are chaperone proteins which are returned to the ER, assisted by KDELR2 receptors in the Golgi membrane. STX18 and NBAS assist in the arrival and fusion of the COPI vesicles to the ER membrane. d S2P response to ER stress. The cleavage of OASIS activates transcription (TF: transcription factor) of genes involved in the ER stress response pathway; COL1A1 transcription is activated by SMAD4. e Extracellular processing of the procollagen type I triple helix and formation of fibrils and fibers. The C- and N-propeptides are cleaved-off by BMP1 and ADAMTS2, 3 or 14, respectively. After cleavage, the formation of collagen fibrils takes place 


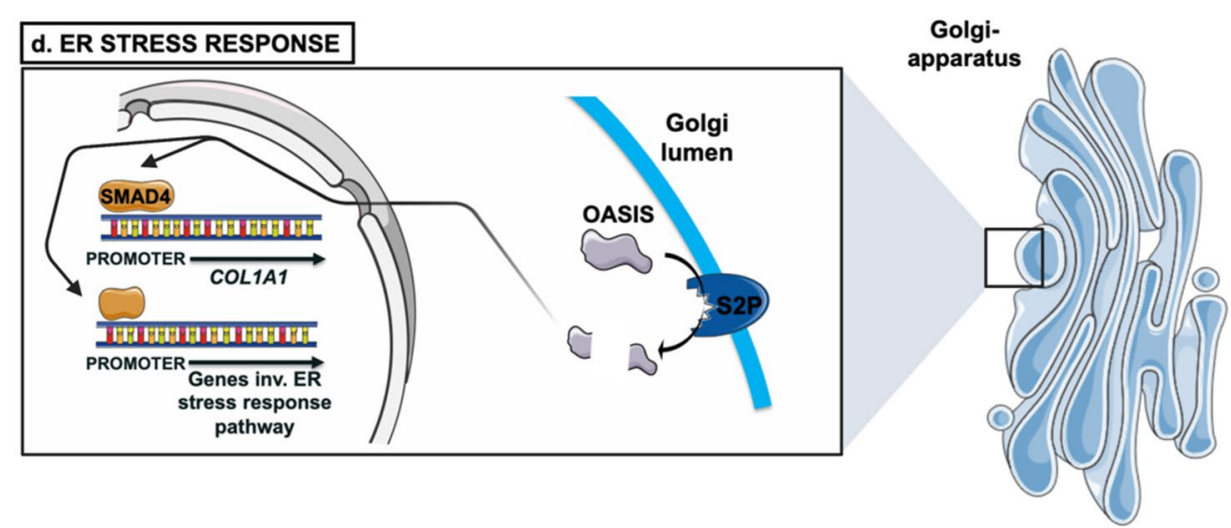

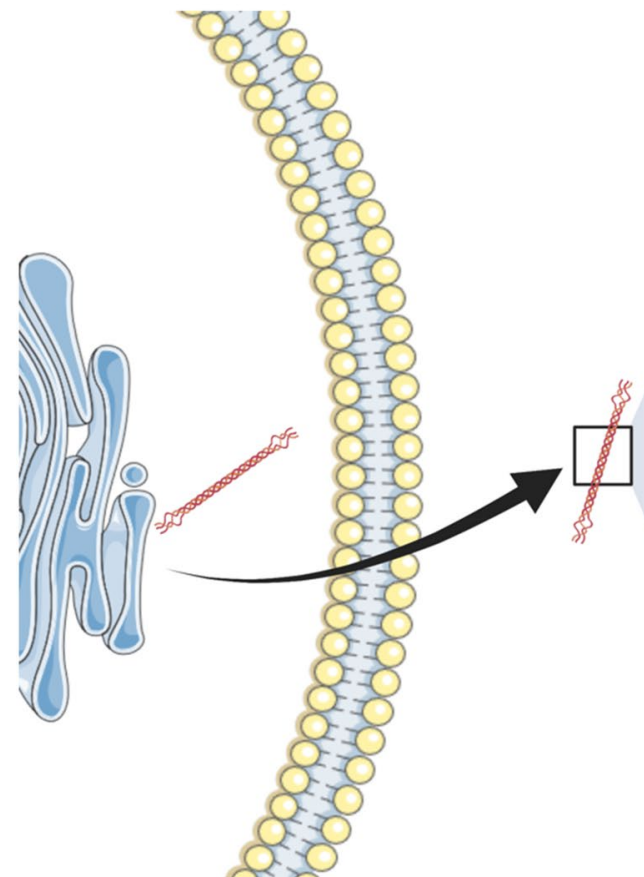

Fig. 1 (continued)

stability (Burjanadze 1979). The conversion of peptide bonds in proline residues from cis to trans conformation takes place by peptidylproline cis-trans isomerase (PPIase), which further facilitates triple helix formation (Bächinger 1987).

In addition to 4-hydroxyproline, collagen also contains 3-hydroxyproline, the functional significance of which is much less understood. This is distinctly found in $\alpha 1$ (Pro986) and $\alpha 2$ (Pro707) collagen type I chains where hydroxylation takes place by LEPRE1 encoding prolyl 3-hydroxylase 1 (P3H1) (Lim et al. 2017). P3H1 forms a heterotrimeric complex together with cartilage associated protein (CRTAP) and cyclophilin B (CYPB), encoded by CRTAP and PPIB respectively. This complex is shown as part of the posttranslational modification in Fig. 1a. Attention to the role of prolyl 3-hydroxylation in collagen integrity was initially

\section{e. EXTRACELLULAR PROCESSING}

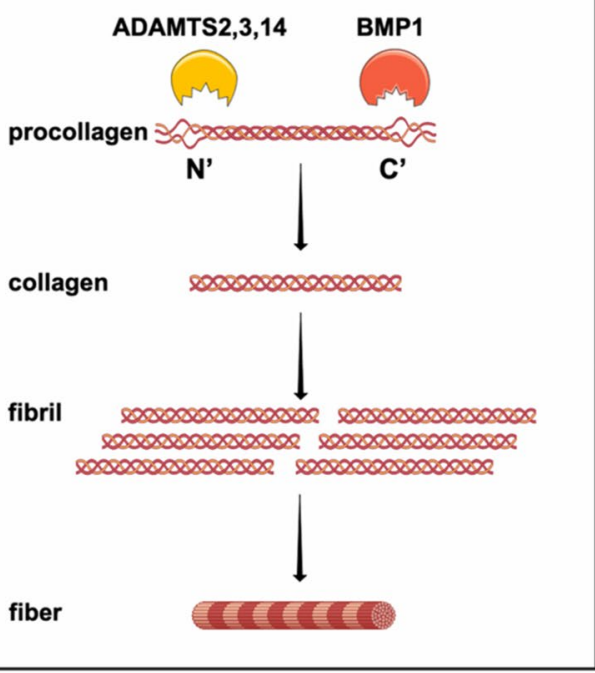

triggered by the discovery of CRTAP mutations as cause for OI, which was demonstrated by collagen overmodification (Morello et al. 2006). The same effect was subsequently reported as a consequence of mutations in LEPRE1 and $P P I B$, clearly pointing to a delay in collagen folding (Cabral et al. 2007; van Dijk et al. 2009a, b). However, upon defects in proteins of this complex, residual amount of 3-hydroxyproline can still often be observed (Marini et al. 2010). This can depend on the effect of the genetic defect, as shown by the presence of 85\% 3-hydroxyproline in a patient in which the ER retention sequence (KDEL) was absent in LEPRE1 (Takagi et al. 2012). Regarding CYPB, it has been reported that mutations in $P P I B$, leading to no protein production, lead to a more severe OI phenotype compared to mutations that result in protein alterations; it is unclear if this relates to the level of residual 3-hydroxyproline (Rush et al. 2014). 
Interestingly, in this complex CRTAP and P3H1 stabilize each other and are thus both needed to form a stable protein complex, while CYPB appears to be independent of both (Pyott et al. 2011; van Dijk et al. 2009a, b). Concerning the mechanism of the complex, different functions have been attributed. The crystal structure of synthetic collagen revealed that the 3-hydroxyl group points out from the triple helix suggesting that it may serve as a recognition point for other proteins which may be involved in collagen fibrillogenesis (Schumacher et al. 2006). In this complex, CYPB has been found to have PPIase activity but it is unclear to which extent this contributes to the collagen abnormalities in relation to its function in the prolyl-3 hydroxylation complex (Homan et al. 2014; Ishikawa et al. 2009).

\section{Lysine hydroxylation}

The hydroxylation of lysine residues in procollagen is also a necessary condition for the production of a functional molecule. This is performed by the PLOD1-3 genes encoding lysyl hydroxylase 1-3 (LH1-3) which convert lysine residues to hydroxylysine (Hyl). Lysyl oxidases subsequently use the Hyl residues to generate pyridinoline cross-links which affect the properties of the bone tissue. Each LH functions in a specific location in procollagen. For instance, LH1 and LH3 hydroxylate lysine residues in the triple helix, while LH2 forms Hyl residues in the telopeptide regions, allowing intermolecular cross-links to take place between collagen fibrils (Gjaltema et al. 2016; Leal et al. 2018; Takaluoma et al. 2007). In recent studies, it has been postulated that LH2 forms a complex with FKBP65 which regulates its hydroxylase activity. The LH2-FKBP65 complex together with HSP47 is shown in Fig. 1a. FKBP65, FK-506-binding protein encoded by $F K B P 10$, is a peptidyl prolyl isomerase and also a type I procollagen chaperone (Barnes et al. 2012; Lim et al. 2017). Gjaltema et al. showed that FKBP65 binds selectively to $\mathrm{LH} 2$ to promote the dimerization of $\mathrm{LH} 2$, and therefore, its function (Gjaltema et al. 2016). Moreover, Duran et al. identified the heat shock protein 47 (HSP47) and $\mathrm{BiP}$ as additional components of the FKBP65-LH2 complex (Duran et al. 2017).

In specific, HSP47 was found to inhibit LH2 access to the hydroxylation site, while FKBP65 promoted dimerization of LH2 and thus an increase in hydroxylation of type I procollagen (Duran et al. 2017). Proper lysine hydroxylation is essential for the activity of lysyl oxidase (LOX), an amine oxidase which deaminates specific lysine and hydroxylysine residues to form allysines in the telopeptide domains (Kagan and $\mathrm{Li}$ 2003). This subsequently facilitates the formation of collagen fibrils in the ECM as later discussed.

Considering the joint action of LH2 and FKBP65, it is not surprising to find similarities in the phenotypic presentation of patients with pathogenic mutations in PLOD2 and
FKBP10, respectively. As expected, mutations in PLOD2 lead to underhydroxylation of the telopeptide lysines in bone type I collagen (Schwarze et al. 2013). Patients with these mutations are classified as having Bruck type 2 syndrome. Bruck syndrome is a rare autosomal recessive disease with great clinical overlap with OI, with the exception of congenital joint contractures and pterygia (Gjaltema et al. 2016; Kelley et al. 2011). Mutations in FKBP10 on the other hand, lead to both Bruck syndrome type 1 and recessive, moderately severe OI type III. The FKBP10 mutations probably lead to these diseases due to the resulting inability of LH2 dimer formation and the ensuing underhydroxylation of the procollagen type I telopeptides, which leads to its slight delayed secretion (Gjaltema et al. 2016; Schwarze et al. 2013). However, no specific location or type of mutation in this gene has been identified as specifically causative for the two diseases, and similarly to OI, phenotypic variability is seen even within families (Schwarze et al. 2013; Setijowati et al. 2012). Notably, mutations in PLODI lead to a different connective tissue disease, the kyphoskoliotic type of Ehlers Danlos syndrome (EDS) (type 8) (Yeowell and Steinmann 1993).

\section{Chaperone activity of HSP47 and FKBP65}

Collagen processing is also mediated by the two chaperone proteins HSP47 and FKBP65 which interact with each other and LH2 (Duran et al. 2017). HSP47 is produced by SERPINH1, it is induced by heat and is co-expressed with collagen (Ishida and Nagata 2011). HSP47 binds to both unfolded propeptides and the folded triple helix but has been described to preferentially bind the latter (Koide et al. 1999). Being an ER-resident protein, it binds to procollagen during its import in the ER in a pH-dependent manner (Satoh et al. 1996). While the $\mathrm{pH}$ is neutral in the ER, it is lower in the Golgi where the procollagen is transported, which allows its dissociation from the HSP47 (Nakai et al. 1992). HSP47 is transcriptionally induced by transforming growth factor $\beta 1$ (TGF $\beta 1$ ) and its protein expression has been reported to be upregulated in response to collagen mutations (Yamamura et al. 1998). Additionally, SERPINH1 mutations not only decrease levels of HSP47, but they also reduce the protein levels of FKBP65. FKBP10 mutations do not reciprocate this effect on HSP47 (Duran et al. 2015).

Patients with absent HSP47 still produce normal, although less stable, type I collagen, but with slightly delayed secretion (Christiansen et al. 2010). The same effect is reported for FKBP10 mutations (Barnes et al. 2012). This suggests that both FKBP65 and HSP47 probably affect collagen biosynthesis after the posttranslational modification stage performed among others by the prolyl-3 hydroxylation complex (Duran et al. 2015). However, a recent study presented an OI case with a homozygous SERPINHI 
substitution in which collagen type I showed overmodification despite normal folding and secretion. This was combined with higher expression level of several procollagen chaperones. It was shown that the mutant HSP47 protein had less affinity for collagen type I, which may possibly lead to local unwinding of the triple helix by lack of triple helix stability. In this way procollagen may be still subjected to overmodification (Syx et al. 2021).

\section{Calcium homeostasis-dependent chaperone activity}

The process of biosynthesis of type I collagen depends heavily on intracellular calcium; $\mathrm{Ca}^{2+}$ binding to the $\mathrm{C}$-terminal globular domain of procollagen stabilizes the process of collagen trimerization and folding by assisting the formation of interchain hydrogen and disulfide bonds. In this process, several chaperone proteins are regulated by the $\mathrm{Ca}^{2+}$ fluctuations in the ER including PDI, CYPB, LH1, LH2 and FKBP65. One of the channels affecting the ER $\mathrm{Ca}^{2+}$ flow is the TRIC-B, shown in Fig. 1a, an intracellular monovalent cation channel, encoded by TMEM38B. A disruption of the ER $\mathrm{Ca}^{2+}$ homeostasis by TMEM38B mutations potentially influences collagen biosynthesis by affecting collagen chaperone proteins (Cabral et al. 2016). Patient cells show decreased collagen secretion due to retention of the defective collagen, which is reported to be less stable owing to decreased helical lysine hydroxylation but increased telopeptide hydroxylation even though increased LH1 and decreased FKBP65 expression was noted respectively (Cabral et al. 2016). Together with TRIC-A and TRIC-B, $\mathrm{Ca}^{2+}$ release is regulated by the inositol triphosphate receptors $\left(\mathrm{IP}_{3} \mathrm{R}\right)$ and ryanodine receptors (RyR). The sarcoplasmic-ER $\mathrm{Ca}^{2+}$-ATPase type $2 \mathrm{~b}$ (SERCA2b) plays a role in calcium uptake. SERCA2b activity requires its coupling to the ER membrane translocation associated membrane protein 2, TRAM2, for collagen translation (Stefanovic et al. 2004). The two TRIC proteins are needed to maintain the $\mathrm{Ca}^{2+}$ homeostasis by providing counter-ion currents to facilitate the $\mathrm{Ca}^{2+}$ release from the intracellular stores by $\mathrm{iP}_{3} \mathrm{R}$ and RyR (Wang et al. 2019). No differences in the expression levels of $\mathrm{IP}_{3} \mathrm{R}$ and SERCA2b are noted in OI patients with TMEM38B mutations (Cabral et al. 2016).

\section{Anterograde vesicle transport}

After the posttranslational modifications and the triple helix folding have been completed in the ER lumen, procollagen is transported from the ER to the Golgi apparatus via vesicle transport (Stephens 2012). However, the transport of the procollagen triple helix is different than most other proteins. This is due to the large size of the triple helix, which is estimated to reach $400 \mathrm{~nm}$. Effective transport may be further complicated by the rigid rod-like element of collagen. This poses a problem since vesicles typically have a diameter of only up to $90 \mathrm{~nm}$ (Raote et al. 2018). For this reason, it has been hypothesized that procollagen secretion takes place in large coat protein II (COPII) vesicles with a diameter between 400 and $1200 \mathrm{~nm}$ (Mccaughey et al. 2019).

Anterograde transport, the trafficking of proteins from the ER to the Golgi, is accomplished with the COPII vesicles which are formed by the concerted action of different proteins, shown in Fig. 1b. The process starts at the ER exit sites where the ER resident SEC12 protein stimulates the exchange of GDP with GTP in the small GTPase SAR1, as a result of which, the SAR1-GTP protein is imbedded in the outer lipid bilayer of the ER. It then recruits the SEC23/ SEC24 heterodimer by interacting with SEC23, forming the inner coat of the COPII vesicle. In the last step, SEC13/ SEC31 binds SEC23/SEC24 heterotetramers in order to activate SEC23, whose GAP activity leads to the hydrolysis of the SAR1-bound GTP; in this structure SEC13/SEC31 form the outer COPII coat and they are crucial for the induction of curvature needed for the spherical vesicle shape (Malhotra and Erlmann 2015).

Cargo proteins in COPII vesicles are commonly recruited by SEC 24 by binding to its specific cargo-binding site. However, this is not the case with soluble proteins which need receptor proteins to anchor them to the vesicle coat (GomezNavarro and Miller 2016). In the case of the bulky procollagen, packaging to vesicles requires the transmembrane proteins transport and Golgi organization 1 (TANGO1) and cutaneous $\mathrm{T}$ cell lymphoma-associated antigen 5 (cTAGE5) proteins. TANGO1 possesses a cytoplasmic, transmembrane and ER luminal domain; the cytoplasmic part interacts with SEC23 and cTAGE5 whereas the luminal domain binds procollagen through HSP47, as shown in Fig. 1b (Ishikawa et al. 2016; Widmer et al. 2012). Although this interaction has been extensively studied in collagen type VII, it has been found that loss of TANGO1 leads to procollagen type I retention in the ER, which clearly extends its involvement to multiple collagen types in agreement with its role in large protein transport (Ma and Goldberg 2016; Ríos-Barrera et al. 2017; Saito et al. 2011). According to Raote et al. TANGO1 forms a ring around the ER secretion point which prevents the recruitment of the outer COPII coat, which ensures that the whole procollagen triple helix is encapsulated before the vesicle closes (Raote et al. 2018). TANGO1 has been also proposed to interact with SEC16 at the ER exit site which influences the GAP activity of SEC23 (Kung et al. 2012); this can also regulate vesicle closure when an appropriate size has been reached (Maeda et al. 2017). In this way TANGO1 acts as cargo receptor for collagen and facilitates the assembly of mega COPII vesicles (Raote et al. 2018; Yuan et al. 2018). Interestingly, another factor that may promote this process, is the ubiquitination of some SEC 31 molecules by the ubiquitin ligase Cullin 3 and its 
adaptor protein KLHL12 (Jin et al. 2012). Even though ubiquitination is primarily known as a protein degradation mechanism, it can also affect protein function. Although the mechanistic details remain to be elucidated, the overexpression of Cullin3-KLHL12 has shown to produce COPII structures of a sufficient size to accommodate collagen (Jin et al. 2012). The concept of collagen transport by vesicles is challenged by findings of a recent study by McCaughey et al. which proposes the possibility of a direct connection between the ER and Golgi apparatus for the transfer of procollagen. This connection is suggested to involve the budding formation of COPII vesicles at the ER site in close proximity to the Golgi apparatus, where TANGO1 mediates their fusion to the ER-Golgi intermediate compartment. After scission, the formed compartment takes on the characteristics of the Golgi apparatus (Mccaughey et al. 2019).

The significance of the anterograde transport in skeletal diseases is exemplified by multiple diseases with genetic defects in genes encoding for components of the COPII procollagen transport (Ohisa et al. 2010). In mammals, gene duplications during evolution have created several paralogs of the COPII components, mutations in which have been found to lead to different syndromes. Loss of functional SEC23A leads to craniolenticulo-satural dysplasia (CLSD), characterized by skeletal defects, facial dysmorphisms hypertelorism and Y-shaped cataracts (Boyadjiev et al. 2011). Mutations in SEC23B lead to congenital dyserythropoietic anemia type II (CDA-II). The disorder shows ineffective erythropoiesis, abnormal bone marrow morphology and anomalous erythrocyte membrane proteins (Ohisa et al. 2010; Schwarz et al. 2009). SEC23B mutations also lead to Cowden syndrome which presents increased predisposition to different cancer types and macrocephaly (Yehia et al. 2015). Pathogenic mutations in another inner COPII coat protein encoding gene, $S E C 24 D$, lead to a syndromic form of OI with a disease presentation between CLSD and Colecarpenter syndrome. Patients show bone deformities, multiple fractures, craniofacial malformations, short stature, but no sign of cataracts (Garbes et al. 2015). Mutations in SARIB cause chylomicron retention disease (CMRD), characterized by enterocyte failure to secrete large lipoprotein particles. Patients show slow growth and weight gain, frequent diarrhea, steatorrhea and hypocholesterolemia (Ohisa et al. 2010). Regarding the outer coat components, mutations in SEC31A cause a neurodevelopmental disorder with spastic quadriplegia, optic atrophy, seizures, and structural brain anomalies; this is accompanied by delayed growth, contractures and clubfoot. Finally, mutations in TANGO1, producing truncated or reduced levels of the protein, lead to a novel autosomal recessive syndrome. Dentinogenesis imperfecta, growth retardation, short stature, hearing loss, insulin-dependent diabetes mellitus and mild intellectual disability are reported (Lekszas et al. 2020). Recently, TANGO1 deficiency was reported to lead to embryonic lethality with skeletal dysplasia and striking undermineralization (Guillemyn et al. 2021). Clearly, impaired COPII transport leads to diverse skeletal abnormalities in combination with many different phenotypic features. It is tempting to assume that this is related to the distinct profile of vesicle cargo proteins affected by each genetic abnormality, including procollagen type I.

\section{Retrograde vesicle transport}

Newly synthesized proteins are transported from the ER to the Golgi apparatus where they can be sorted to their destination (Aoki et al. 2009). However, some of these proteins have to be transported back to the ER where they exert their function; this happens by retrograde transport. Unlike COPII-coated vesicles in anterograde transport, retrograde transport of proteins from the Golgi to the ER takes place in vesicles with a COPI coating. In contrast to the separate inner and outer coat structure found in COPII vesicles, COPI coating is composed of seven subunits ( $\alpha$-COP, $\beta$ '-COP, $\varepsilon$-COP, $\beta$-COP, $\delta$-COP, $\gamma$-COP and $\zeta$-COP), shown in Fig. 1c (Arakel and Schwappach 2018). The assembly of the COPI-coated vesicles at the Golgi membrane starts with the activation and binding of the small GTPase ARF1 to the membrane; in mammalian cells the protein GBF1 has been suggested to catalyze the association of GTP with ARF1 (Kawamoto et al. 2002). This leads to the assembly of the coat complex in which three haptameers make up its basic unit. Vesicle budding is allowed when the GTP in ARF1 is hydrolyzed back to GDP. Sorting of proteins back to the ER is based on the presence of the common retrograde KKXX motif, to which the $\alpha$-COP and $\beta$ '-COP subunits are described to bind (Letourneur et al. 1994; Raykhel et al. 2007). In addition, certain proteins such as the KDEL receptor, also mediate the sorting of ER proteins by binding COPI and functioning as an adaptor as shown in Fig. 1c (Shibuya et al. 2015). Receptors of this family include KDELR1, KDELR2 and KDELR3, each consisting of 7 transmembrane domains. These receptors recognize proteins that have to be returned back to the ER by binding to their C-terminal Lys-Asp-Glu-Leu (KDEL) motif (Capitani and Sallese 2009); variations of the KDEL sequence also exist. The binding of the receptor to the KDEL(-like)containing protein is $\mathrm{pH}$-regulated. The acidic lumen of the Golgi promotes the interaction of the KDEL receptor with the KDEL motif in the cargo protein. This contributes to the formation of the COPI vesicles and the subsequent retrograde transport. Once found in the ER, the less acidic environment leads to the release of the protein cargo from the KDEL receptor, the latter of which is then recycled back to the Golgi (Wu et al. 2020).

Considering that collagen type I is heavily subjected to many types of posttranslational modifications, it is safe to 
conclude that correct collagen maturation requires substantial contribution from many chaperones, many of which are proteins that reside in the ER. For this reason, it is not surprising that the retrograde protein transport, which facilitates chaperone regulation, is emerging as a key mechanism in OI pathology. We recently showed that mutations in KDELR2 lead to OI type II and III, which was accompanied by a decrease of procollagen chaperone proteins HSP47 and FKBP65 in fibroblasts of the patients. This also correlated with decreased secretion of procollagen type I and the lack of proper collagen fiber assembly. Notably, HSP47 was found associated with the extracellular monomeric and multimeric collagen molecules (van Dijk et al. 2020). HSP47 and procollagen are known to dissociate from each other at ER exit sites before collagen's anterograde transport; it remains to be investigated how this process is disrupted in cells with KDELR2 mutations (Omari et al. 2020).

Both HSP47 and FKBP65 have a KDEL-like domain (Table 2) which can account for their decreased expression in patients with KDELR2 mutations. However, given that the expression of FKBP65 has been reported to be influenced by the availability of HSP47, it is not clear to which extent this is the case in these patients (Duran et al. 2015). In addition to HSP47 and FKBP65, there are several more proteins with a KDEL(-like) motif which play a role in collagen regulation (Table 2). Of these, LEPRE1 and P4HB have a KDEL motif and mutations in both are known to cause OI and Cole-Carpenter syndrome respectively. Other collagen chaperones with a KDEL(-like) motif have not been identified to cause OI/bone-related disorders.

Another protein involved in retrograde transport is the neuroblastoma-amplified gene protein, NBAS (Aoki et al. 2009). NBAS is a peripheral protein, which forms a subunit of the Syntaxin 18 (STX18) complex by binding to the $\mathrm{p} 31$

Table 2 KDEL motif-containing proteins implicated in collagen biosynthesis

\begin{tabular}{llll}
\hline Gene & Motif & Protein & Disease association \\
\hline SERPINH1 & RDEL & HSP47 & OI \\
GRP78 & KDEL & HSPA5 / BIP & No specific associated disease \\
P3H2 & KDEL & LEPREL1 & Cataract \\
P3H3 & REEL & LEPREL2 & No specific associated disease \\
P4HB/PDIA1 & KDEL & PDIA1 & Cole-Carpenter syndrome \\
FKBP10 & HEEL & FKBP65 & Bruck syndrome \\
P3H1 & KDEL & LEPRE1 & OI \\
HSP90B1 & KDEL & GRP94 & No specific associated disease \\
PDIA2/PDIP & KEEL & PDIA2 & No specific associated disease \\
PDIA4 & KEEL & PDIA4 & No specific associated disease \\
PDIA5 & KEEL & PDIA5 & No specific associated disease \\
PDIA6 & KDEL & PDIA6 & No specific associated disease \\
\hline
\end{tabular}

$P D I$ protein disulphide isomerase part of STX18 as shown in Fig. 1c. Syntaxin 18 plays a role in the membrane fusion of retrograde transport vesicles with the acceptor ER compartment (Balasubramanian et al. 2017; Iinuma et al. 2009; Segarra et al. 2015). NBAS has also been presented to play a role in nonsense mediated mRNA decay (NMD) which selectively degrades mRNA with a premature stop termination codon to prevent accumulation of truncated proteins that could interfere with cellular functions (Balasubramanian et al. 2017). NMD also has a role in regulating endogenous mRNA expression of genes with an osteogenic function (Longman et al. 2013). NBAS has been associated with an autosomal recessive disorder called short stature with optic atrophy and Pelger-Huët anomaly (SOPH) syndrome. Patients have features such as short stature, acute liver failure, optic nerve atrophy, facial dysmorphisms and Pelger-Huët anomaly of leucocytes (Balasubramanian et al. 2017; Maksimova et al. 2010). Balasubramanian et al. presented two patients having heterozygous mutations in NBAS showing OI characteristics such as short stature, bone fragility and developmental delay (Balasubramanian et al. 2017). In addition, the patients also presented atypical OI features such as optic atrophy, immunodeficiency and abnormal liver function tests, which overlap with the SOPH syndrome phenotype. Fibroblasts from a patient showed decreased collagen secretion and variable shaped collagen fibrils. It is plausible that NBAS defects lead to bone abnormalities by disturbed retrograde transport and/or compromised NMD targeting of bone-related genes. Recently, mutations in $A R C N 1$, encoding the coatomer subunit delta of COPI, have also been shown to lead to a syndrome of craniofacial deformities which correlated with ER stress and reduced collagen secretion in ARCN1 knockdown fibroblasts (Izumi et al. 2016). Regarding other bone-related diseases caused by defects in the components of the COPI vesicles, mutations in the COPA gene cause COPA syndrome, an autosomal dominant autoimmune disease, characterized by arthritis and inflammation of the lungs, kidneys and joints (Patwardhan and Spencer 2019).

\section{ER stress response in OI}

In addition to feeding protein trafficking to the Golgi, ER is a main cell site for protein quality control which is consistent with the high abundance of ER-resident chaperones. Exposure of hydrophobic regions, cysteine residues and protein aggregates signal folding errors to chaperones such as BiP, Calnexin, Calreticulin, GRP94 and PDI which bind to the misfolded proteins to retain them in the ER (Ellgaard and Helenius 2003); the latter 2 are KDEL(-like) motif proteins. Accumulation of misfolded proteins can be sensed by the ER, in response to which the unfolded protein response (UPR) is activated. UPR ensures that the abnormal protein 
stays in the ER until its conformation can be improved by the chaperones. If the protein is defective beyond repair, it is destined for degradation. This can happen by ERassociated degradation (ERAD), by which the protein is transported to the cytoplasm where it is ubiquitinated and subsequently degraded by the proteasome. An alternative pathway is autophagy by which the irreversibly damaged protein become degraded in lysosomes.

However, if the ER stress is prolonged, at a certain stage cell death can ensue (Tsai and Weissman 2010). The UPR mechanism stems from three different receptors on the ER membrane, activating transcription factor 6 (ATF6), inositol-requiring protein 1 (IRE1) and PKR-like ER kinase (PERK). Notably, the KDEL-containing protein BiP occupies the lumenal domain of all three receptors; increase in ER-unfolded proteins frees the receptors from $\mathrm{BiP}$ as the latter migrates to bind to the problematic proteins (Gardner et al. 2013). Activation of ATF6 by ER stress results in its translocation to the Golgi where it is sequentially cleaved by the site metalloprotease 1 (S1P) and 2 (S2P), which gives rise to the active transcription factor which can then regulate the expression of UPR-related genes, such as the cytoplasmic X-box binding protein 1 (XBP1), encoded by the corresponding gene $X B P 1$, and CCAAT/enhancerbinding protein homologous protein (CHOP), encoded by the gene DDIT3 (DNA damage Inducible Transcript 3) (Yang et al. 2020). IRE1 activation leads to the removal of an intron from XBP1 mRNA, producing the isoform XBP1s; $\mathrm{XBP} 1 \mathrm{~s}$ regulates chaperone and ERAD protein expression (Chen and Brandizzi 2013). The activation of PERK also has an important role as it phosphorylates eIF2 $\alpha$ which can decrease the ER load during ER stress as it inhibits protein translation. However, the translation of activating transcription factor 4 (ATF4) is allowed to take place in agreement with its role in gene expression regulation mediating cell death (Wortel et al. 2017).

Given that severe OI is largely a disease of misfolded protein, it can be easily deduced that ER stress is part of the underlying mechanism. Even though OI was originally solely considered as a disease of structural defects, it has been long ago recognized that the activation of ER stress and of related pathways also deserve attention in OI development. This is evident by the identification of OI causative genes in components participating in the UPR pathway. One of these is the site 2 metalloprotease (S2P), encoded by the membrane-bound transcription factor peptidase site 2 (MBTPS2). This is a cleaving protease located on the Golgi membrane, involved in the ER stress response and cholesterol metabolism (Lindert et al. 2016). One of the proteins cleaved by S2P upon ER stress is the old astrocyte specifically induced substance (OASIS), encoded by the cAMP responsive element binding protein 3-like 1 (CREB3L1), also a rare cause of OI, shown in Fig. 1d. After cleavage, this transcription factor is shuttled to the nucleus to activate the transcription of genes involved in the ER stress response pathway or UPR pathway. The cleaved OASIS also binds to the COL1A1 promoter via SMAD4 to increase collagen type I expression, shown in Fig. 1d (Lindert et al. 2016). Keller et al. also presented OASIS as playing a possible upstream role in the formation of the COPII complex, through regulation of the COPII inner coat component SEC24D (Keller et al. 2018).

Mutations in MBTPS2 lead to X-linked moderate OI as well as other syndromes depending on the location of the mutation (Lindert et al. 2016). These include IFAP/ BRESHECK, characterized by ichithyosis follicularis, atrichia and photophobia (Corujeira et al. 2013), keratosis follicularis spinulosa decalvans (KFSD), characterized by scarring alopecia of the scalp, eyebrows and axillae (Malvankar and Sacchidanand 2015), and Olmsted syndrome, characterized by bilateral mutilating transgradient palmoplantar keratoderma and periorificial keratotic plaques (Duchatelet and Hovnanian 2015). Of these only the first shows skeletal abnormalities and vertebral anomalies, including scoliosis and chest hypoplasia. In X-linked OI, reduction of OASIS cleavage fragments was observed, which subsequently led to less type I procollagen secretion. In addition, the expression of both CREB3L1 and its nucleus complex partner SMAD4 were reduced during osteoblast differentiation (Lindert et al. 2016). The severity of the OI phenotype can differ enormously depending on the location of the mutations and their allelic status; in the first reported families, biallelic mutations lead to embryonic lethality whereas in the latter two, biallelic patients were reported to survive infancy despite severe skeletal deformities (Cayami et al. 2019; Guillemyn et al. 2019; Symoens et al. 2013). Interestingly, members of the described family with monoallelic mutations in CREB $3 L 1$ presented a mild OI clinical picture with blue sclera, osteopenia and few fractures (Keller et al. 2018). It is suspected that less functional OASIS leads to less expression of SEC24D which in turn disrupts COPII formation and subsequently gives way to less efficient secretion of type I collagen and other bone matrix proteins in osteoblasts (Keller et al. 2018).

Activation of UPR has been also demonstrated in collagen type I mutations. BiP was originally reported to increase and specifically associate with C-terminal procollagen mutations, and not in fibroblasts with mutations in the helical domain (Chessler and Byers 1993; Lamandé et al. 1995). However, a more recent study showed that BiP, as well as phosphorylated PERK and ATF4 expression and splicing of XBP1, can be increased in fibroblasts with helical mutations. In the same study, the defective collagen was shown to accumulate in the cell ER and lead to autophagy and apoptosis. Treatment with the FDA-approved chemical chaperone 4-phenylbutyrate, a histone deacetylase inhibitor, 
could reduce UPR stress, and enhanced protein clearance by stimulating autophagy (Besio et al. 2018). Enlarged ER due to the retention of misfolded collagen has been also shown in OI patient fibroblasts with mutations in CRTAP, $P P I B$, and $P 3 H 1$ impairing prolyl-3 hydroxylation. This generally coincided with activation of UPR, as shown by the upregulation of BiP, phosphorylated PERK and ATF4, as well as autophagy and apoptosis. Also, here, 4-phenylbutyrate decreased the size of ER cisternae and was able to reduce UPR and apoptosis (Besio et al. 2019). This highlights abnormal collagen trafficking as a common therapeutic avenue for different genetic causes of OI which can be counteracted by alleviating ER stress.

Given the promising results of the chemical chaperones in alleviating OI ER stress, it is important to comprehend the underlying mechanism which can lead to more targeted interventions. Currently, little is known about how the different ER stress branches directly affect the different steps of collagen type I regulation. However, a recent study, from DiChiara et al., interestingly showed that forced expression of $X B P 1$ in OI fibroblasts with a glycine substitution, markedly increased COL1Al expression and that this even improved mutant collagen type I folding. On the contrary, activation of the ATF6 pathway had no effect on collagen secretion. It will be exciting to see if these findings can be reproduced in OI osteoblasts and other dominant negative collagen mutations. In summary, OI mutations affecting collagen type I structure can have different effects. Detection of overmodified collagen shows that it is possible for collagen to escape the quality control of the cells (Van Dijk et al. 2009a, b). In other cases, this leads to chronic ER stress and reduced production of collagen (Lindert et al. 2018; van Dijk et al. 2020). The trafficking of unfolded COL $1 \alpha 2$ to the Golgi for subsequent lysosome-dependent degradation has been also reported in the absence of COL $1 \alpha 1$ chains (Gotkin et al. 2004). Future investigations may be able to determine how this outcome depends on specific collagen defects.

\section{Extracellular processing}

Procollagen trafficking after the Golgi complex entails its destination to the extracellular matrix. At the Golgi apparatus, procollagen type I is still in possession of a propeptide at each of its two ends which prevents its premature assembly into fibrils (Mienaltowski and Birk 2014). Once secreted to the ECM, procollagen type I is exposed to the proteolytic activity of BMP1/tolloid-like proteinases and ADAMTS 2,3 and 14 which cleave off the $\mathrm{C}$ - and $\mathrm{N}$-procollagen domains respectively. After cleavage, the triple helix remains in the center flanked by short non-collagenous sequences called telopeptides. The fully formed type I collagen molecules then assemble spontaneously into quarter-staggered arrays which allows their close packing in the collagen fibrils (Gelse et al. 2003; Mienaltowski and Birk 2014). This process is shown in Fig. 1e.

Despite the fact that extracellular processing takes place in the ECM, it is still dependent on proper intracellular trafficking which ensures that procollagen is correctly primed for ECM processing. This means that the hydroxylation of lysine residues in the procollagen triple helical and telopeptide regions in the ER by LH enzymes is paramount for the integrity of the collagen fibrils since they serve as recognition points for LOX. This allows the formation of crosslinks between telopeptides and the triple helix of collagen molecules, which promotes the arrangement of the mature collagen molecules into fibrils with a distinctive $67 \mathrm{~nm}$ axial periodicity (Tzaphlidou 2001). The detrimental consequences of lack of LOX activity on collagen fibrillogenesis are seen after incubation of osteoblasts with the enzymatic inhibitor, $\beta$-aminopropionitrile (BAPN), as a result of which crosslinks and osteoblast differentiation are dysregulated (Turecek et al. 2008). This is also in agreement with the defective crosslinking seen in patients with OI/Bruck syndrome patients with PLOD2 and FKBP10 mutations (Gistelinck et al. 2020). This also highlights the need for impeccable coordination with COPI trafficking which delivers the FKBP65 back to the ER to make it available for procollagen hydroxylation. Interestingly, loss of function mutations in $L O X$, are not involved in OI, but in thoracic aortic aneurysms and dissections (Corradi et al. 2015).

Certain connective tissue disorders occur by mutations in enzymes regulating procollagen cleavage. Recessive mutations in ADAMTS2 lead to dermatosparaxis EDS type 7 , characterized by extreme skin fragility in combination with short limbs, hand and feet, craniofacial features and osteopenia while recessive mutations in ADAMTS3 lead to Hennekam lymphangiectasia-lymphedema syndrome 3, characterized by primary lymphedema in the lower extremities (Malfait et al. 2017; Mead and Apte 2018). Mutations in $B M P 1$ cause autosomal recessive OI due to defects in the extracellular processing of procollagen type I, more specific defective C-propeptide removal and potential subsequent cross-linking defects (Eyre and Weis 2013; Marini et al. 2014). Patients have fragile bones, but a high mineral density, recurrent fractures, generalized bone deformity and osteopenia (Eyre and Weis 2013; Pollitt et al. 2016). Similarly, OI patients with C-propeptide cleavage site mutations are also reported to have high bone mass (Lindahl et al. 2011). Interestingly, BMP1 also processes LOX, which makes it indispensable in ECM collagen processing (Uzel et al. 2001).

Although it is established that the transport of procollagen to the plasma membrane is mediated by microtubuleassociated secretory vacuoles budding off from the Golgi, it is unclear how collagens find their way to their allocated 
location and at which point their sorting route diverges (Leblond 1989; Weinstock and Leblond 1974). For example, while procollagen I is targeted to all ECM sites of the cell, procollagens IV and VII are destined to the cell basal membrane (Malhotra and Erlmann 2015). TANGO is known to recognize collagen types I, IV and VII, although perhaps not with the same efficiency (Malhotra and Erlmann 2015). Future studies will show at which stage of collagen trafficking, the distinct localization of different collagen types is determined. It has been suggested that the formation of new collagen fibers occurs in fibripositors which are extensions of the plasma membrane (Canty et al. 2004; Kadler et al. 2008). It is important to mention that the formation of fibrils does not only depend on the intrinsic collagen properties but also on other molecules which bind to collagen; small leucine-rich repeat proteoglycans (SLRPs) such as decorin, biglycan, fibromodulin and lumican can affect collagen fibril diameter (Chen and Birk 2013). Fibronectin and integrins are also described as major regulators of fibril assembly as shown by the disruption of fibrillogenesis when their binding to collagen is blocked ( $\mathrm{Li}$ et al. 2003; McDonald et al. 1982). Fibril assembly determines the mechanical properties of bone tissue not only by the quality of the collagen fibers themselves but also by mineralization (Nair et al. 2013; Wenger et al. 2007).

\section{Discussion}

The identification of numerous genetic causes of OI in the last years has not only improved patient diagnosis, but in parallel has also given insight in multiple levels of collagen regulation and the clinical consequences arising from their dysregulation. It has been suggested that a mechanism-based classification of OI would provide a basis for extension of the existing classification system, which could also serve in the future as a basis for the development of treatment (Forlino and Marini 2016). This review recapitulates our understanding of collagen trafficking, highlighting the significance of anterograde and retrograde transport. Based on the current state of knowledge in this review of the literature (Table 1), limited conclusions can be drawn on genotype-phenotype correlations which points to the fact that we still need to understand critical factors in the regulating mechanism as well as intrafamilial and interfamilial OI variation (Forlino and Marini 2016; Zhytnik et al. 2020). This variation is also reflected in the international Osteogenesis Imperfecta Variant Database where individual mutations can lead to different clinical OI types (https://oi. gene.le.ac.uk). A general trend supports an occurrence of a mild phenotype arising from less collagen production (nullallele) and a more severe phenotype as a result of structural collagen abnormalities from collagen defects or defects in collagen-modifying enzymes (Zhytnik et al. 2019). Also, in certain cases, the severity of the phenotype can be explained by the effect of the mutation. For example, OI patients with BMP1 mutations with residual activity of the BMP1 protein have a milder clinical presentation compared to patients with BMP1 null mutations (Pollitt et al. 2016). However, the effect of the mutation still does not correlate with high bone mineral density which is found in some of the patients. Owing to the lack of clear genotype-phenotype correlation, the testing of all known OI genes is generally recommended in new OI patients.

Even though the clinical variability is a well-recognized OI feature which has been attributed to modifier genes, almost no study exist addressing this issue (Fitzgerald et al. 2013). The use of Genomic Mismatch Scanning-based method that physically identifies shared genomic regions between family members, revealed loci in Amish families descended from a common founder, that can potentially serve as modifier genes in OI. One of the loci was PTGS2 encoding cyclooxynase 2 (COX2), which is involved in bone development by expression in osteoblasts (Brooks et al. 2009). Regarding clinical variation in OI caused by dominant negative collagen mutations, it can be hypothesized that different levels of chaperone expression may be able to regulate structural abnormalities which may consequently affect phenotypic presentation. However, experimental evidence supporting influence of chaperone levels on collagen overmodification or phenotypic presentation of dominant negative collagen OI is still lacking (Besio et al. 2018). The presence of miRNAs regulating osteogenesis may also influence OI progression which warrants investigation (NCT04009733; clinicaltrials.gov) (Kaneto et al. 2014). Considering the complexity of the OI mechanism, we recommend the use of the Sillence clinical classification with a note of the genetic defect as the most effective way to communicate the disease based on the current state of knowledge. We also hope that in the coming years the scientific community will deliver advancements towards explaining the clinical variability of OI.

In this review, only genes with a direct relation in the regulation of collagen were discussed. For this reason, the review did not address the OI causative genes SERPINF1, FAM46A, SPARC, SP7, CCDC134, IFITM5, MESD, WNT1 and $P L S 3$, although this does not exclude the possibility that they might influence collagen regulation. Absence of evidence for collagen-related regulation may be also attributed to the fact that certain genes may not have been sufficiently investigated in human bone tissue, which is the most relevant tissue in studying skeletal pathology in OI. This review is also preferentially focused on studies with human cells and diseases, so the insights of animal models in collagen trafficking were not discussed. 
The trafficking of collagen is an intricate process and its smooth orchestration is essential for the composition and mechanical properties of the bone tissue (Canty and Kadler 2005). The formation of collagen fibrils is the end product of the transition of collagen in several cell compartments through which it is subjected in a controllable manner to gradual maturation. Recent findings on the anterograde and retrograde transport, stress the fact that correct collagen regulation does not only require its own effective transportation across the protein transport system of the cells but also the proper trafficking of chaperone molecules on which procollagen relies for its conformational integrity. This means that mechanisms contributing to collagen chaperone regulation, such as their retrograde transport back to the ER, warrant investigation in OI. This is particularly evident from the recent identification of the KDELR2 receptor as a causative gene for OI, which specifically facilitates the Golgi-ER recycling of KDEL(-like) motif-containing collagen chaperones (van Dijk et al. 2020). Not all mutated components of the COPII and COPI vesicles affect skeletogenesis, which may partially reflect their mechanistic impact on collagen regulation. The ER has been long recognized as the main location of posttranslational modifications for procollagen. In cases of collagen retention, ER stress pathways are activated, a common effect in both collagen and non-collagen mutations (Besio et al. 2019; Chessler and Byers 1993; Lamandé et al. 1995; Tsai and Weissman 2010). Interestingly, calcium depletion has been shown to stimulate the cell secretion of ER resident which can be attenuated by KDEL receptors the expression of which is increased under ER stress (Trychta et al. 2018).

This provides an exciting thought about the way calcium fluctuations in TMEM $38 B$ OI mutations could influence KDEL-containing OI chaperones, considering that they are also known to cause ER stress (Cabral et al. 2016).

Therapy for OI is currently not administered on a genetic defect type basis. OI patients are most commonly treated with orthopedic procedures aiming to rectify skeletal deformity and bisphosphonates, which are anticatabolic drugs for osteoporosis (Etich et al. 2020a). Bisphosphanates are analogs of pyrophosphate with affinity for bone hydroxyapatite to which they bind to inhibit osteoclast activity (Rogers et al. 2020). Also, medications in OI clinical trials such as BPS804 (NCT01417091; clinicaltrials. gov) and Romosozumab (NCT04545554; clinicaltrials. gov) (neutralizing anti-sclerostin antibodies), Denosumab (NCT01799798; clinicaltrials.gov) (neutralizing anti-RANKL antibody) and a combination of teriparitide (parathyroid hormone analog) with zolendronic acid (NCT01679080; clinicaltrials.gov) were originally not designed specifically for OI-related fractures. Similarly to bisphosphonates, denosumab also has antiresorptive activity as it blocks the RANKL ligand that stimulates osteoclastogenesis (Baron et al. 2011). On the contrary, medications of sclerostin antibodies and teripartide are considered to have an osteoanabolic effect. They both stimulate osteoblast function and survival; blocking of sclerostin inhibits WNT signaling which normally hinders osteoblast differentiation (Lewiecki 2014). Teriparatide, an analog of human parathyroid hormone, also stimulates osteoblast function by binding to its receptor (Bodenner et al. 2007).

An exception to that is Fresolimumab (NCT03064074; clinicaltrials.gov) (neutralizing anti-TGF- $\beta$ antibody) which specifically targets TGF- $\beta$ signaling in OI with CRTAP and COL1A2 defects (Grafe et al. 2014). TGF- $\beta$ signaling is known to stimulate osteoblast differentiation (Bonewald and Mundy 1990). Considering the promising results of chemical chaperones in alleviating ER stress, we anticipate that this will be a promising therapeutic avenue for diverse defects in chaperone transport leading to ER procollagen retention (Besio et al. 2018). However, none of the published studies have shown improvement of collagen overmodification which characterizes structural defects in collagen (Besio et al. 2018; Gioia et al. 2017; Takeyari et al. 2020). Chemical chaperones can have different molecular effects; thus, it remains to be discovered how they specifically decrease ER stress and collagen accumulation in OI cells (Wong and Shoulders 2019). In addition, we envision that it could be possible in the future to treat collagen defects based on their type. A pharmacological approach enhancing collagen production could be ideal for patients with quantitative collagen mutations, whereas gene therapy could allow targeting of mutations leading to structural collagen defects.

Based on the above, it is clear that collagen transport is a central process in OI pathogenesis, the many stages of which influence the assembly of collagen fibrils, dictating bone quality. Chaperone regulation through retrograde transport deserves attention as a critical point affecting collagen maturation and ultimately bone development. We hope that the insights in these pathways will stimulate research towards this direction to further unravel the molecular sequence leading to bone fragility in OI.

Acknowledgements Figure 1 was created with BioRender.com by using adapted images from SERVIER MEDICAL ART provided by Les Laboratoires Servier, which falls under the creative commons' attribution 3.0 unported license.

Author contributions All authors have contributed substantially to the conception of the article and critical revision.

Funding The work of Lauria Claeys, Dimitra Micha and Gerard Pals was funded by the kind donation of Hans Horsting and Mary HorstingStuit of the Horstingstuit foundation. Dimitra Micha is also funded by the Amsterdam Movement Sciences Innovation call grant. 
Availability of data and material Not applicable.

Code availability Not applicable.

\section{Declarations}

Conflict of interest On behalf of all authors, the corresponding author states that there is no conflict of interest.

Ethics approval Not applicable.

Consent to participate Not applicable.

Consent for publication Not applicable.

Open Access This article is licensed under a Creative Commons Attribution 4.0 International License, which permits use, sharing, adaptation, distribution and reproduction in any medium or format, as long as you give appropriate credit to the original author(s) and the source, provide a link to the Creative Commons licence, and indicate if changes were made. The images or other third party material in this article are included in the article's Creative Commons licence, unless indicated otherwise in a credit line to the material. If material is not included in the article's Creative Commons licence and your intended use is not permitted by statutory regulation or exceeds the permitted use, you will need to obtain permission directly from the copyright holder. To view a copy of this licence, visit http://creativecommons.org/licenses/by/4.0/.

\section{References}

Alanay Y, Avaygan H, Camacho N, Utine GE, Boduroglu K, Aktas D, Alikasifoglu M, Tuncbilek E, Orhan D, Bakar FT, Zabel B, Superti-Furga A, Bruckner-Tuderman L, Curry CJR, Pyott S, Byers PH, Eyre DR, Baldridge D, Lee B, Merrill AE, Davis EC, Cohn DH, Akarsu N, Krakow D (2010) Mutations in the gene encoding the RER protein FKBP65 cause autosomal-recessive Osteogenesis Imperfecta. Am J Hum Genet 86:551-559. https:// doi.org/10.1016/j.ajhg.2010.02.022

Aoki T, Ichimura S, Itoh A, Kuramoto M, Shinkawa T, Isobe T, Tagaya M (2009) Identification of the neuroblastoma-amplified gene product as a component of the syntaxin 18 complex implicated in Golgi-to-endoplasmic reticulum retrograde transport. $\mathrm{MBoC}$ 20:2639-2649. https://doi.org/10.1091/mbc.e08-11-1104

Arakel EC, Schwappach B (2018) Formation of COPI-coated vesicles at a glance. J Cell Sci. https://doi.org/10.1242/jcs.209890

Ashournia H, Johansen FT, Folkestad L, Diederichsen ACP, Brixen K (2015) Heart disease in patients with osteogenesis imperfecta-a systematic review. Int J Cardiol 196:149-157. https://doi.org/10. 1016/j.ijcard.2015.06.001

Bächinger HP (1987) The influence of peptidyl-prolyl cis-trans isomerase on the in vitro folding of type III collagen. J Biol Chem 262:17144-17148

Bacon S, Crowley R (2018) Developments in rare bone diseases and mineral disorders. Ther Adv Chronic Dis 9:51-60. https://doi. org/10.1177/2040622317739538

Balasubramanian M, Hurst J, Brown S, Bishop NJ, Arundel P, DeVile C, Pollitt RC, Crooks L, Longman D, Caceres JF, Shackley F, Connolly S, Payne JH, Offiah AC, Hughes D, Parker MJ, Hide W, Skerry TM (2017) Compound heterozygous variants in NBAS as a cause of atypical Osteogenesis Imperfecta. Bone 94:65-74. https://doi.org/10.1016/j.bone.2016.10.023
Baldridge D, Schwarze U, Morello R, Lennington J, Bertin TK, Pace JM, Pepin MG, Weis M, Eyre DR, Walsh J, Lambert D, Green A, Robinson H, Michelson M, Houge G, Lindman C, Martin J, Ward J, Lemyre E, Mitchell JJ, Krakow D, Rimoin DL, Cohn DH, Byers PH, Lee B (2008) CRTAP and LEPRE1 mutations in recessive osteogenesis imperfecta. Hum Mutat 29:1435-1442. https://doi.org/10.1002/humu.20799

Barnes AM, Carter EM, Cabral WA, Weis M, Chang W, Makareeva E, Leikin S, Rotimi CN, Eyre DR, Raggio CL, Marini JC (2010) Lack of cyclophilin B in osteogenesis imperfecta with normal collagen folding. N Engl J Med 362:521-528. https://doi.org/10. 1056/NEJMoa0907705

Barnes AM, Cabral WA, Weis M, Makareeva E, Mertz EL, Leikin S, Eyre D, Trujillo C, Marini JC (2012) Absence of FKBP10 in recessive type XI osteogenesis imperfecta leads to diminished collagen cross-linking and reduced collagen deposition in extracellular matrix. Hum Mutat 33:1589-1598. https://doi.org/10. 1002/humu.22139

Baron R, Ferrari S, Russell RG (2011) Denosumab and bisphosphonates: different mechanisms of action and effects. Bone 48:677692. https://doi.org/10.1016/j.bone.2010.11.020

Becker J, Semler O, Gilissen C, Li Y, Bolz HJ, Giunta C, Bergmann C, Rohrbach M, Koerber F, Zimmermann K, De Vries P, Wirth B, Schoenau E, Wollnik B, Veltman JA, Hoischen A, Netzer C (2011) Exome sequencing identifies truncating mutations in human SERPINF1 in autosomal-recessive osteogenesis imperfecta. J Hum Genet 88:362-371. https://doi.org/10.1016/j.ajhg. 2011.01.015

Besio R, Iula G, Garibaldi N, Cipolla L, Sabbioneda S, Biggiogera M, Marini JC, Rossi A, Forlino A (2018) 4-PBA ameliorates cellular homeostasis in fibroblasts from osteogenesis imperfecta patients by enhancing autophagy and stimulating protein secretion. Biochim Biophys Acta Mol Basis Dis 1864:16421652. https://doi.org/10.1016/j.bbadis.2018.02.002

Besio R, Garibaldi N, Leoni L, Cipolla L, Sabbioneda S, Biggiogera M, Mottes M, Aglan M, Otaify GA, Temtamy SA, Rossi A, Forlino A (2019) Cellular stress due to impairment of collagen prolyl hydroxylation complex is rescued by the chaperone 4-phenylbutyrate. Dis Model Mech. https://doi.org/10.1242/ dmm.038521

Bodenner D, Redman C, Riggs A (2007) Teriparatide in the management of osteoporosis. Clin Interv Aging 2:499-507. https://doi. org/10.2147/cia.s241

Bonewald LF, Mundy GR (1990) Role of transforming growth factorbeta in bone remodeling. Clin Orthop Relat Res 250:261-276

Boudko SP, Engel J, Bächinger HP (2012) The crucial role of trimerization domains in collagen folding. Int J Biochem Cell Biol 44:21-32. https://doi.org/10.1016/j.biocel.2011.09.009

Boyadjiev S, Kim S-D, Hata A, Haldeman-Englert C, Zackai E, Naydenov C, Hamamoto S, Schekman R, Kim J (2011) Craniolenticulo-sutural dysplasia associated with defects in collagen secretion. Clin Genet 80:169-176. https://doi.org/10.1111/j. 1399-0004.2010.01550.x

Brooks P, Marcaillou C, Vanpeene M, Saraiva JP, Stockholm D, Francke S, Favis R, Cohen N, Rousseau F, Tores F, Lindenbaum P, Hager J, Philippi A (2009) Robust physical methods that enrich genomic regions identical by descent for linkage studies: confirmation of a locus for osteogenesis imperfecta. BMC Genet 10:16. https://doi.org/10.1186/1471-2156-10-16

Burjanadze TV (1979) Hydroxyproline content and location in relation to collagen thermal stability. Biopolymers 18:931-938. https://doi.org/10.1002/bip.1979.360180413

Byers PH, Wallis GA, Willing MC (1991) Osteogenesis Imperfecta: translation of mutation to phenotype. J Med Genet 28:433-442. https://doi.org/10.1136/jmg.28.7.433 
Cabral WA, Chang W, Barnes AM, Weis M, Scott MA, Leikin S, Makareeva E, Kuznetsova NV, Rosenbaum KN, Tifft CJ, Bulas DI, Kozma C, Smith PA, Eyre DR, Marini JC (2007) Prolyl 3-hydroxylase 1 deficiency causes a recessive metabolic bone disorder resembling lethal/severe osteogenesis imperfecta. Nat Genet 39:359-365. https://doi.org/10.1038/ng1968

Cabral WA, Ishikawa M, Garten M, Makareeva EN, Sargent BM, Weis MA, Barnes AM, Webb EA, Shaw NJ, Ala-Kokko L, Lacbawan FL, Högler W, Leikin S, Blank PS, Zimmerberg J, Eyre DR, Yamada Y, Marini JC (2016) Absence of the ER cation channel TMEM38B/TRIC-B disrupts intracellular calcium homeostasis and dysregulates collagen synthesis in recessive osteogenesis imperfecta. PLOS Genet 12:e1006156. https:// doi.org/10.1371/journal.pgen.1006156

Canty EG, Kadler KE (2005) Procollagen trafficking, processing and fibrillogenesis. J Cell Sci 118:1341-1353. https://doi.org/10. $1242 /$ jcs. 01731

Canty EG, Lu Y, Meadows RS, Shaw MK, Holmes DF, Kadler KE (2004) Coalignment of plasma membrane channels and protrusions (fibripositors) specifies the parallelism of tendon. $\mathbf{J}$ Cell Biol 165:553-563. https://doi.org/10.1083/jcb.200312071

Capitani M, Sallese M (2009) The KDEL receptor: new functions for an old protein. FEBS Lett 583:3863-3871. https://doi.org/ 10.1016/j.febslet.2009.10.053

Cayami FK, Maugeri A, Treurniet S, Setijowati ED, Teunissen BP, Eekhoff EMW, Pals G, Faradz SM, Micha D (2019) The first family with adult osteogenesis imperfecta caused by a novel homozygous mutation in CREB3L1. Mol Genet Genom Med 7:e823-e823. https://doi.org/10.1002/mgg3.823

Chen S, Birk DE (2013) The regulatory roles of small leucinerich proteoglycans in extracellular matrix assembly. FEBS J 280:2120-2137. https://doi.org/10.1111/febs.12136

Chen Y, Brandizzi F (2013) IRE1: ER stress sensor and cell fate executor. Trends Cell Biol 23:547-555. https://doi.org/10.1016/j.tcb. 2013.06.005

Chessler SD, Byers PH (1993) BiP binds type I procollagen pro alpha chains with mutations in the carboxyl-terminal propeptide synthesized by cells from patients with osteogenesis imperfecta. J Biol Chem 268:18226-18233

Christiansen HE, Schwarze U, Pyott SM, Alswaid A, Balwi MA, Alrasheed S, Pepin MG, Weis MA, Eyre DR, Byers PH (2010) Homozygosity for a missense mutation in SERPINH1, which encodes the collagen chaperone protein HSP47, results in severe recessive osteogenesis imperfecta. PLoS Genet 86:389-398. https://doi.org/10.1016/j.ajhg.2010.01.034

Copyright (C) 1993-2021, University of Washington, Seattle. GeneReviews is a registered trademark of the University of Washington, Seattle. All rights reserved, Seattle (WA)

Corradi M, Monti E, Venturi G, Gandini A, Mottes M, Antoniazzi F (2015) The recurrent causal mutation for osteogenesis imperfecta type $\mathrm{V}$ occurs at a highly methylated $\mathrm{CpG}$ dinucleotide within the IFITM5 gene. J Pediatr Genet 03:035-039. https://doi.org/ 10.3233/pge-14079

Corujeira S, Águeda S, Monteiro G, Canelhas A, Sampaio M, Rocha R, Leão M (2013) Expanding the phenotype of IFAP/BRESECK syndrome: a new case with severe hypogammaglobulinemia. Eur J Med Genet 56:603-605. https://doi.org/10.1016/j.ejmg.2013. 09.005

Doyard M, Bacrot S, Huber C, Di Rocco M, Goldenberg A, Aglan MS, Brunelle P, Temtamy S, Michot C, Otaify GA, Haudry C, Castanet M, Leroux J, Bonnefont JP, Munnich A, Baujat G, Lapunzina P, Monnot S, Ruiz-Perez VL, Cormier-Daire V (2018) FAM46A mutations are responsible for autosomal recessive osteogenesis imperfecta. J Med Genet 55:278-284. https://doi.org/10.1136/ jmedgenet-2017-104999
Dubail J, Brunelle P, Baujat G, Huber C, Doyard M, Michot C, Chavassieux P, Khairouni A, Topouchian V, Monnot S, Koumakis E, Cormier-Daire V (2020) Homozygous loss-of-function mutations in CCDC134 are responsible for a severe form of osteogenesis imperfecta. J Bone Miner Res 35:1470-1480. https://doi.org/10. 1002/jbmr.4011

Duchatelet S, Hovnanian A (2015) Olmsted syndrome: clinical, molecular and therapeutic aspects. Orphanet J Rare Dis 10:33. https:// doi.org/10.1186/s13023-015-0246-5

Duran I, Nevarez L, Sarukhanov A, Wu S, Lee K, Krejci P, Weis M, Eyre D, Krakow D, Cohn DH (2015) HSP47 and FKBP65 cooperate in the synthesis of type I procollagen. Hum Mol Genet 24:1918-1928. https://doi.org/10.1093/hmg/ddu608

Duran I, Martin JH, Weis MA, Krejci P, Konik P, Li B, Alanay Y, Lietman C, Lee B, Eyre D, Cohn DH, Krakow D (2017) A chaperone complex formed by HSP47, FKBP65, and BiP modulates telopeptide lysyl hydroxylation of type I procollagen. J Bone Miner Res 32:1309-1319. https://doi.org/10.1002/jbmr.3095

Ellgaard L, Helenius A (2003) Quality control in the endoplasmic reticulum. Nat Rev Mol Cell Biol 4:181-191. https://doi.org/10. 1038/nrm1052

Engel J, Prockop DJ (1991) The zipper-like folding of collagen triple helices and the effects of mutations that disrupt the zipper. Annu Rev Biophys Biophys Chem 20:137-152. https://doi.org/ 10.1146/annurev.bb.20.060191.001033

Etich J, Leßmeier L, Rehberg M, Sill H, Zaucke F, Netzer C, Semler O (2020a) Osteogenesis imperfecta-pathophysiology and therapeutic options. Mol Cell Pediatr 7:9-9. https://doi.org/10.1186/ s40348-020-00101-9

Etich J, Rehberg M, Eckes B, Sengle G, Semler O, Zaucke F (2020b) Signaling pathways affected by mutations causing osteogenesis imperfecta. Cell Signal 76:109789. https://doi.org/10.1016/j.cells ig.2020.109789

Eyre DR, Weis MA (2013) Bone collagen: new clues to its mineralization mechanism from recessive osteogenesis imperfecta. Calcif Tissue Int 93:338-347. https://doi.org/10.1007/ s00223-013-9723-9

Fahiminiya S, Majewski J, Mort J, Moffatt P, Glorieux FH, Rauch F (2013) Mutations in WNT1 are a cause of osteogenesis imperfecta. J Med Genet 50:345-348. https://doi.org/10.1136/jmedg enet-2013-101567

Farber CR, Reich A, Barnes AM, Becerra P, Rauch F, Cabral WA, Bae A, Quinlan A, Glorieux FH, Clemens TL, Marini JC (2014) A novel IFITM5 mutation in severe atypical osteogenesis imperfecta type VI impairs osteoblast production of pigment epithelium-derived factor. J Bone Miner Res 29:1402-1411. https:// doi.org/10.1002/jbmr.2173

Fiscaletti M, Biggin A, Bennetts B, Wong K, Briody J, Pacey V, Birman C, Munns CF (2018) Novel variant in Sp7/Osx associated with recessive osteogenesis imperfecta with bone fragility and hearing impairment. Bone 110:66-75. https://doi.org/10.1016/j. bone.2018.01.031

Fitzgerald J, Holden P, Wright H, Wilmot B, Hata A, Steiner RD, Basel D (2013) Phenotypic variability in individuals with type $\mathrm{V}$ osteogenesis imperfecta with identical IFITM5 mutations. J Rare Disord 1:37-42

Forlino A, Marini JC (2016) Osteogenesis imperfecta. Lancet 387:1657-1671. https://doi.org/10.1016/S0140-6736(15) 00728-X

Gajko-Galicka A (2002) Mutations in type I collagen genes resulting in osteogenesis imperfecta in humans. Acta Biochim Polon 49:433-441

Garbes L, Kim K, Rieß A, Hoyer-Kuhn H, Beleggia F, Bevot A, Kim MJ, Huh YH, Kweon H-S, Savarirayan R, Amor D, Kakadia PM, Lindig T, Kagan KO, Becker J, Boyadjiev SA, Wollnik B, Semler O, Bohlander SK, Kim J, Netzer C (2015) REPORT mutations in 
SEC24D, encoding a component of the COPII machinery, cause a syndromic form of osteogenesis imperfecta. Am J Hum Genet 96:432-439. https://doi.org/10.1016/j.ajhg.2015.01.002

Gardner BM, Pincus D, Gotthardt K, Gallagher CM, Walter P (2013) Endoplasmic reticulum stress sensing in the unfolded protein response. Cold Spring Harb Perspect Biol 5:a013169. https:// doi.org/10.1101/cshperspect.a013169

Gelse K, Pöschl E, Aigner T (2003) Collagens-structure, function, and biosynthesis. Adv Drug Deliv 55:1531-1546. https://doi.org/ 10.1016/j.addr.2003.08.002

Gioia R, Tonelli F, Ceppi I, Biggiogera M, Leikin S, Fisher S, Tenedini E, Yorgan TA, Schinke T, Tian K, Schwartz JM, Forte F, Wagener R, Villani S, Rossi A, Forlino A (2017) The chaperone activity of 4PBA ameliorates the skeletal phenotype of Chihuahua, a zebrafish model for dominant osteogenesis imperfecta. Hum Mol Genet 26:2897-2911. https://doi.org/10.1093/hmg/ ddx 171

Gistelinck C, Weis M, Rai J, Schwarze U, Niyazov D, Song KM, Byers PH, Eyre DR (2020) Abnormal bone collagen cross-linking in osteogenesis imperfecta/bruck syndrome caused by compound heterozygous PLOD2 mutations. JBMR plus. https://doi.org/10. 1002/jbm4.10454

Gjaltema RAF, Van Der Stoel MM, Boersema M, Bank RA (2016) Disentangling mechanisms involved in collagen pyridinoline crosslinking: the immunophilin FKBP65 is critical for dimerization of lysyl hydroxylase 2. Proc Natl Acad Sci USA 113:7142-7147. https://doi.org/10.1073/pnas.1600074113

Glorieux FH (2001) A disease of the osteoblast. Lancet 358:S45. https://doi.org/10.1016/S0140-6736(01)07058-1

Gomez-Navarro N, Miller EA (2016) COP-coated vesicles. Curr Biol 26:R54-r57. https://doi.org/10.1016/j.cub.2015.12.017

Gotkin MG, Ripley CR, Lamande SR, Bateman JF, Bienkowski RS (2004) Intracellular trafficking and degradation of unassociated proalpha2 chains of collagen type I. Exp Cell Res 296:307-316. https://doi.org/10.1016/j.yexcr.2004.01.029

Grafe I, Yang T, Alexander S, Homan EP, Lietman C, Jiang MM, Bertin T, Munivez E, Chen Y, Dawson B, Ishikawa Y, Weis MA, Sampath TK, Ambrose C, Eyre D, Bächinger HP, Lee B (2014) Excessive transforming growth factor- $\beta$ signaling is a common mechanism in osteogenesis imperfecta. Nat Med 20:670-675. https://doi.org/10.1038/nm.3544

Guillemyn B, Kayserili H, Demuynck L, Sips P, De Paepe A, Syx D, Coucke PJ, Malfait F, Symoens S (2019) A homozygous pathogenic missense variant broadens the phenotypic and mutational spectrum of CREB3L1-related osteogenesis imperfecta. Hum Mol Genet 28:1801-1809. https://doi.org/10.1093/hmg/ddz017

Guillemyn B, Nampoothiri S, Syx D, Malfait F, Symoens S (2021) Loss of TANGO1 leads to absence of bone mineralization. JBMR plus 5:e10451. https://doi.org/10.1002/jbm4.10451

Hanagata N (2016) IFITM5 mutations and osteogenesis imperfecta. J Bone Miner Metab 34:123-131. https://doi.org/10.1007/ s00774-015-0667-1

Hayat A, Hussain S, Bilal M, Kausar M, Almuzzaini B, Abbas S, Tanveer A, Khan A, Siddiqi S, Foo JN, Ahmad F, Khan F, Khan B, Anees M, Mäkitie O, Alfadhel M, Ahmad W, Umair M (2020) Biallelic variants in four genes underlying recessive osteogenesis imperfecta. Eur J Med Genet. https://doi.org/10.1016/j.ejmg. 2020.103954

Homan EP, Lietman C, Grafe I, Lennington J, Morello R, Napierala D, Jiang MM, Munivez EM, Dawson B, Bertin TK, Chen Y, Lua R, Lichtarge O, Hicks J, Weis MA, Eyre D, Lee BH (2014) Differential effects of collagen prolyl 3-hydroxylation on skeletal tissues. PLoS Genet 10:e1004121. https://doi.org/10.1371/journ al.pgen.1004121

Iinuma T, Aoki T, Arasaki K, Hirose H, Yamamoto A, Samata R, Hauri HP, Arimitsu N, Tagaya M, Tani K (2009) Role of syntaxin 18 in the organization of endoplasmic reticulum subdomains. J Cell Sci 122:1680-1690. https://doi.org/10.1242/jcs.036103

Ishida Y, Nagata K (2011) Hsp47 as a collagen-specific molecular chaperone. Methods Enzymol 499:167-182. https://doi.org/10. 1016/b978-0-12-386471-0.00009-2

Ishikawa Y, Wirz J, Vranka JA, Nagata K, Bächinger HP (2009) Biochemical characterization of the prolyl 3-hydroxylase 1.cartilage-associated protein.cyclophilin B complex. J Biol Chem 284:17641-17647. https://doi.org/10.1074/jbc.M109.007070

Ishikawa Y, Ito S, Nagata K, Sakai LY, Bächinger HP (2016) Intracellular mechanisms of molecular recognition and sorting for transport of large extracellular matrix molecules. Proc Natl Acad Sci USA 113:E6036-e6044. https://doi.org/10.1073/pnas.16095 71113

Izumi K, Brett M, Nishi E, Drunat S, Tan E-S, Fujiki K, Lebon S, Cham B, Masuda K, Arakawa M, Jacquinet A, Yamazumi Y, Chen S-T, Verloes A, Okada Y, Katou Y, Nakamura T, Akiyama T, Gressens P, Foo R, Passemard S, Tan E-C, El Ghouzzi V, Shirahige K (2016) ARCN1 mutations cause a recognizable craniofacial syndrome due to COPI-mediated transport defects. Am J Hum Genet 99:451-459. https://doi.org/10.1016/j.ajhg. 2016.06.011

Jin L, Pahuja KB, Wickliffe KE, Gorur A, Baumgärtel C, Schekman R, Rape M (2012) Ubiquitin-dependent regulation of COPII coat size and function. Nature 482:495-500. https://doi.org/10.1038/ nature 10822

Kadler KE, Hill A, Canty-Laird EG (2008) Collagen fibrillogenesis: fibronectin, integrins, and minor collagens as organizers and nucleators. Curr Opin Cell Biol 20:495-501. https://doi.org/10. 1016/j.ceb.2008.06.008

Kagan HM, Li W (2003) Lysyl oxidase: properties, specificity, and biological roles inside and outside of the cell. J Cell Biochem 88:660-672. https://doi.org/10.1002/jcb.10413

Kaneto CM, Lima PS, Zanette DL, Prata KL, Pina Neto JM, de Paula FJ, Silva WA Jr (2014) COL1A1 and miR-29b show lower expression levels during osteoblast differentiation of bone marrow stromal cells from Osteogenesis Imperfecta patients. BMC Med Genet 15:45. https://doi.org/10.1186/1471-2350-15-45

Kawamoto K, Yoshida Y, Tamaki H, Torii S, Shinotsuka C, Yamashina S, Nakayama K (2002) GBF1, a guanine nucleotide exchange factor for ADP-ribosylation factors, is localized to the cis-Golgi and involved in membrane association of the COPI coat. Traffic 3:483-495. https://doi.org/10.1034/j.1600-0854.2002.30705.x

Keller RB, Tran TT, Pyott SM, Pepin MG, Savarirayan R, McGillivray G, Nickerson DA, Bamshad MJ, Byers PH (2018) Monoallelic and biallelic CREB3L1 variant causes mild and severe osteogenesis imperfecta, respectively. Genet Med 20:411-419. https://doi. org/10.1038/gim.2017.115

Kelley BP, Malfait F, Bonafe L, Baldridge D, Homan E, Symoens S, Willaert A, Elcioglu N, Van Maldergem L, Verellen-Dumoulin C, Gillerot Y, Napierala D, Krakow D, Beighton P, Superti-Furga A, De Paepe A, Lee B (2011) Mutations in FKBP10 cause recessive osteogenesis imperfecta and bruck syndrome. J Bone Miner Res 26:666-672. https://doi.org/10.1002/jbmr.250

Koide T, Asada S, Nagata K (1999) Substrate recognition of collagenspecific molecular chaperone HSP47. Structural requirements and binding regulation. J Biol Chem 274:34523-34526. https:// doi.org/10.1074/jbc.274.49.34523

Koivu J, Myllylä R (1987) Interchain disulfide bond formation in types $\mathrm{I}$ and II procollagen. Evidence for a protein disulfide isomerase catalyzing bond formation. J Biol Chem 262:6159-6164

Kung LF, Pagant S, Futai E, D'Arcangelo JG, Buchanan R, Dittmar JC, Reid RJ, Rothstein R, Hamamoto S, Snapp EL, Schekman R, Miller EA (2012) Sec24p and Sec16p cooperate to regulate the GTP cycle of the COPII coat. EMBO J 31:1014-1027. https:// doi.org/10.1038/emboj.2011.444 
Lamandé SR, Chessler SD, Golub SB, Byers PH, Chan D, Cole WG, Sillence DO, Bateman JF (1995) Endoplasmic reticulum-mediated quality control of type I collagen production by cells from osteogenesis imperfecta patients with mutations in the pro alpha 1 (I) chain carboxyl-terminal propeptide which impair subunit assembly. J Biol Chem 270:8642-8649. https://doi.org/10.1074/ jbc.270.15.8642

Lamande S, Bateman J (1999) Procollagen folding and assembly: the role of endoplasmic reticulum enzymes and molecular chaperones. Semin Cell Dev Biol 10:455-464. https://doi.org/10.1006/ scdb.1999.0317

Lapunzina P, Aglan M, Temtamy S, Caparrós-Martín JA, Valencia M, Letón R, Martínez-Glez V, Elhossini R, Amr K, Vilaboa N, RuizPerez VL (2010) Identification of a frameshift mutation in osterix in a patient with recessive osteogenesis imperfecta. Am J Hum Genet 87:110-114. https://doi.org/10.1016/j.ajhg.2010.05.016

Leal GF, Nishimura G, Voss U, Bertola DR, Åström E, Svensson J, Yamamoto GL, Hammarsjö A, Horemuzova E, Papadogiannakis N, Iwarsson E, Grigelioniene G, Tham E (2018) Expanding the clinical spectrum of phenotypes caused by pathogenic variants in PLOD2. J Bone Miner Res 33:753-760. https://doi.org/10. 1002/jbmr.3348

Leblond CP (1989) Synthesis and secretion of collagen by cells of connective tissue, bone, and dentin. Anat Rec 224:123-138. https:// doi.org/10.1002/ar.1092240204

Lekszas C, Foresti O, Raote I, Liedtke D, König EM, Nanda I, Vona B, Coster PD, Cauwels R, Malhotra V, Haaf T (2020) Biallelic TANGO1 mutations cause a novel syndromal disease due to hampered cellular collagen secretion. Elife. https://doi.org/10. 7554/eLife.51319

Letourneur F, Gaynor EC, Hennecke S, Démollière C, Duden R, Emr SD, Riezman H, Cosson P (1994) Coatomer is essential for retrieval of dilysine-tagged proteins to the endoplasmic reticulum. Cell 79:1199-1207. https://doi.org/10.1016/0092-8674(94) 90011-6

Lewiecki EM (2014) Role of sclerostin in bone and cartilage and its potential as a therapeutic target in bone diseases. Ther Adv Musculoskelet Dis 6:48-57. https://doi.org/10.1177/1759720x13 510479

Li S, Van Den Diepstraten C, D'Souza SJ, Chan BM, Pickering JG (2003) Vascular smooth muscle cells orchestrate the assembly of type I collagen via alpha2beta1 integrin, RhoA, and fibronectin polymerization. Am J Pathol 163:1045-1056. https://doi.org/10. 1016/s0002-9440(10)63464-5

Lim J, Grafe I, Alexander S, Lee B (2017) Genetic causes and mechanisms of osteogenesis imperfecta. Bone 102:40-49. https://doi. org/10.1016/j.bone.2017.02.004

Lindahl K, Barnes AM, Fratzl-Zelman N, Whyte MP, Hefferan TE, Makareeva E, Brusel M, Yaszemski MJ, Rubin CJ, Kindmark A, Roschger P, Klaushofer K, McAlister WH, Mumm S, Leikin S, Kessler E, Boskey AL, Ljunggren O, Marini JC (2011) COL1 C-propeptide cleavage site mutations cause high bone mass osteogenesis imperfecta. Hum Mutat 32:598-609. https://doi. org/10.1002/humu.21475

Lindahl K, Åström E, Rubin C-J, Grigelioniene G, Malmgren B, Ljunggren Ö, Kindmark A (2015) Genetic epidemiology, prevalence, and genotype-phenotype correlations in the Swedish population with osteogenesis imperfecta. EJHG 23:1042-1050. https://doi. org/10.1038/ejhg.2015.81

Lindert U, Cabral WA, Ausavarat S, Tongkobpetch S, Ludin K, Barnes AM, Yeetong P, Weis M, Krabichler B, Srichomthong C, Makareeva EN, Janecke AR, Leikin S, Röthlisberger B, Rohrbach M, Kennerknecht I, Eyre DR, Suphapeetiporn K, Giunta C, Marini JC, Shotelersuk V (2016) MBTPS2 mutations cause defective regulated intramembrane proteolysis in X-linked osteogenesis imperfecta. Nat Commun. https://doi.org/10.1038/ncomms 11920
Lindert U, Gnoli M, Maioli M, Bedeschi MF, Sangiorgi L, Rohrbach M, Giunta C (2018) Insight into the pathology of a COL1A1 signal peptide heterozygous mutation leading to severe osteogenesis imperfecta. Calcif Tissue Int 102:373-379. https://doi.org/10. 1007/s00223-017-0359-z

Longman D, Hug N, Keith M, Anastasaki C, Patton EE, Grimes G, Cáceres JF (2013) DHX34 and NBAS form part of an autoregulatory NMD circuit that regulates endogenous RNA targets in human cells, zebrafish and Caenorhabditis elegans. Nucleic Acids Res 41:8319-8331. https://doi.org/10.1093/nar/gkt585

Ma W, Goldberg J (2016) TANGO1/cTAGE5 receptor as a polyvalent template for assembly of large COPII coats. Proc Natl Acad Sci 113:10061-10066

Maeda M, Katada T, Saito K (2017) TANGO1 recruits Sec16 to coordinately organize ER exit sites for efficient secretion. J Cell Biol 216:1731-1743. https://doi.org/10.1083/jcb.201703084

Maksimova N, Hara K, Nikolaeva I, Chun-Feng T, Usui T, Takagi M, Nishihira Y, Miyashita A, Fujiwara H, Oyama T, Nogovicina A, Sukhomyasova A, Potapova S, Kuwano R, Takahashi H, Nishizawa M, Onodera O (2010) Neuroblastoma amplified sequence gene is associated with a novel short stature syndrome characterised by optic nerve atrophy and Pelger-Huët anomaly. J Med Genet 47:538-548. https://doi.org/10.1136/jmg.2009.074815

Malfait F, Francomano C, Byers P, Belmont J, Berglund B, Black J, Bloom L, Bowen JM, Brady AF, Burrows NP, Castori M, Cohen H, Colombi M, Demirdas S, De Backer J, De Paepe A, Fournel-Gigleux S, Frank M, Ghali N, Giunta C, Grahame R, Hakim A, Jeunemaitre X, Johnson D, Juul-Kristensen B, Kapferer-Seebacher I, Kazkaz H, Kosho T, Lavallee ME, Levy H, Mendoza-Londono R, Pepin M, Pope FM, Reinstein E, Robert L, Rohrbach M, Sanders L, Sobey GJ, Van Damme T, Vandersteen A, van Mourik C, Voermans N, Wheeldon N, Zschocke J, Tinkle B (2017) The 2017 international classification of the Ehlers-Danlos syndromes. Am J Med Genet C Semin Med Genet 175:8-26. https://doi.org/10.1002/ajmg.c.31552

Malhotra V, Erlmann P (2015) The pathway of collagen secretion. Annu Rev Cell Dev Biol 31:109-124. https://doi.org/10.1146/ annurev-cellbio-100913-013002

Malvankar DD, Sacchidanand S (2015) Keratosis follicularis spinulosa decalvans: a report of three cases. Int J Tricol 7:125-128. https://doi.org/10.4103/0974-7753.167461

Marini JC, Cabral WA, Barnes AM (2010) Null mutations in LEPRE1 and CRTAP cause severe recessive osteogenesis imperfecta. Cell Tissue Res 339:59-70. https://doi.org/10. 1007/s00441-009-0872-0

Marini JC, Reich A, Smith SM (2014) Osteogenesis imperfecta due to mutations in non-collagenous genes: lessons in the biology of bone formation. Curr Opin Pedr 26:500-507. https://doi.org/ 10.1097/MOP.0000000000000117

Martínez-Glez V, Valencia M, Caparrós-Martín JA, Aglan M, Temtamy S, Tenorio J, Pulido V, Lindert U, Rohrbach M, Eyre D, Giunta C, Lapunzina P, Ruiz-Perez VL (2012) Identification of a mutation causing deficient BMP1/mTLD proteolytic activity in autosomal recessive osteogenesis imperfecta. Hum Mutat 33:343-350. https://doi.org/10.1002/humu.21647

Mccaughey J, Stevenson NL, Cross S, Stephens DJ (2019) ER-togolgi trafficking of procollagen in the absence of large carriers. J Cell Biol 218:929-948

McDonald JA, Kelley DG, Broekelmann TJ (1982) Role of fibronectin in collagen deposition: Fab' to the gelatin-binding domain of fibronectin inhibits both fibronectin and collagen organization in fibroblast extracellular matrix. J Cell Biol 92:485-492. https://doi.org/10.1083/jcb.92.2.485

Mead TJ, Apte SS (2018) ADAMTS proteins in human disorders. Matrix Biol 71-72:225-239. https://doi.org/10.1016/j.matbio. 2018.06.002 
Mendoza-Londono R, Fahiminiya S, Majewski J, Tétreault M, Nadaf J, Kannu P, Sochett E, Howard A, Stimec J, Dupuis L, Roschger P, Klaushofer K, Palomo T, Ouellet J, Al-Jallad H, Mort JS, Moffatt P, Boudko S, Bächinger H-P, Rauch F (2015) Recessive osteogenesis imperfecta caused by missense mutations in SPARC. Am J Hum Genet 96:979-985. https://doi.org/ 10.1016/j.ajhg.2015.04.021

Mienaltowski MJ, Birk DE (2014) Structure, physiology, and biochemistry of collagens. Progress Herit Soft Connect Tissue Dis 802:5-29. https://doi.org/10.1007/978-94-007-7893-1_2

Migliaccio S, Barbaro G, Fornari R, Di Lorenzo G, Celli M, Lubrano C, Falcone S, Fabbrini E, Greco E, Zambrano A, Brama M, Prossomariti G, Marzano S, Marini M, Conti F, D’Eufemia P, Spera G (2009) Impairment of diastolic function in adult patients affected by osteogenesis imperfecta clinically asymptomatic for cardiac disease: casuality or causality? Int J Cardiol 131:200-203. https://doi.org/10.1016/j.ijcard.2007.10.051

Moosa S, Yamamoto GL, Garbes L, Keupp K, Maia S, Saraiva J, Honjo RS, Kim CA, Menezes HCD, Canella T, Carniero B, Giunta C, Rohrbach M, Janner M, Nu P, Cavalcanti DP, Zabel B, Warman ML (2019) Autosomal-recessive mutations in MESD cause osteogenesis imperfecta. Am J Hum Genet. https://doi.org/10.1016/j.ajhg.2019.08.008

Morello R, Bertin TK, Chen Y, Hicks J, Tonachini L, Monticone M, Castagnola P, Rauch F, Glorieux FH, Vranka J, Bächinger HP, Pace JM, Schwarze U, Byers PH, Weis M, Fernandes RJ, Eyre DR, Yao Z, Boyce BF, Lee B (2006) CRTAP is required for prolyl 3-hydroxylation and mutations cause recessive osteogenesis imperfecta. Cell 127:291-304. https://doi.org/10.1016/j. cell.2006.08.039

Moul A, Alladin A, Navarrete C, Abdenour G, Rodriguez MM (2013) Osteogenesis imperfecta due to compound heterozygosity for the LEPRE1 gene. Fetal Pediatr Pathol 32:319-325. https://doi.org/10.3109/15513815.2012.754528

Murakami T, Hino S, Nishimura R, Yoneda T, Wanaka A, Imaizumi K (2011) Distinct mechanisms are responsible for osteopenia and growth retardation in OASIS-deficient mice. Bone 48:514523. https://doi.org/10.1016/j.bone.2010.10.176

Nair AK, Gautieri A, Chang S-W, Buehler MJ (2013) Molecular mechanics of mineralized collagen fibrils in bone. Nat Commun 4:1724. https://doi.org/10.1038/ncomms2720

Nakai A, Satoh M, Hirayoshi K, Nagata K (1992) Involvement of the stress protein HSP47 in procollagen processing in the endoplasmic reticulum. J Cell Biol 117:903-914. https://doi.org/ 10.1083/jcb.117.4.903

Ohisa S, Inohaya K, Takano Y, Kudo A (2010) Sec24d encoding a component of COPII is essential for vertebra formation, revealed by the analysis of the medaka mutant. Vbi 342:85-95. https://doi.org/10.1016/j.ydbio.2010.03.016

Omari S, Makareeva E, Gorrell L, Jarnik M, Lippincott-Schwartz J, Leikin S (2020) Mechanisms of procollagen and HSP47 sorting during ER-to-Golgi trafficking. Matrix Biol 93:79-94. https:// doi.org/10.1016/j.matbio.2020.06.002

Patwardhan A, Spencer CH (2019) An unprecedented COPA gene mutation in two patients in the same family: comparative clinical analysis of newly reported patients with other known COPA gene mutations. Pediatr Rhematol. https://doi.org/10.1186/ s12969-019-0359-9

Pollitt RC, Saraff V, Dalton A, Webb EA, Shaw NJ, Sobey GJ, Mughal MZ, Hobson E, Ali F, Bishop NJ, Arundel P, Högler W, Balasubramanian M (2016) Phenotypic variability in patients with osteogenesis imperfecta caused by BMP1 mutations. Am J Med Genet 170:3150-3156. https://doi.org/10. 1002/ajmg.a.37958

Pyott SM, Schwarze U, Christiansen HE, Pepin MG, Leistritz DF, Dineen R, Harris C, Burton BK, Angle B, Kim K, Sussman
MD, Weis M, Eyre DR, Russell DW, McCarthy KJ, Steiner RD, Byers PH (2011) Mutations in PPIB (cyclophilin B) delay type I procollagen chain association and result in perinatal lethal to moderate osteogenesis imperfecta phenotypes. Hum Mol Genet 20:1595-1609. https://doi.org/10.1093/hmg/ddr037

Pyott SM, Tran TT, Leistritz DF, Pepin MG, Mendelsohn NJ, Temme RT, Fernandez BA, Elsayed SM, Elsobky E, Verma I, Nair S, Turner EH, Smith JD, Jarvik GP, Byers PH (2013) WNT1 mutations in families affected by moderately severe and progressive recessive osteogenesis imperfecta. Am J Hum Genet 92:590-597. https://doi.org/10.1016/j.ajhg.2013.02.009

Radunovic Z, Steine K (2015) Prevalence of cardiovascular disease and cardiac symptoms: left and right ventricular function in adults with osteogenesis imperfecta. Can J Cardiol 31:1386-1392. https://doi.org/10.1016/j.cjca.2015.04.016

Raghunath M, Bruckner P, Steinmann B (1994) Delayed triple helix formation of mutant collagen from patients with osteogenesis imperfecta. J Mol Biol 236:940-949. https://doi.org/10.1006/ jmbi.1994.1199

Raote I, Ortega-Bellido M, Santos AJM, Foresti O, Zhang C, GarciaParajo MF, Campelo F, Malhotra V (2018) TANGO1 builds a machine for collagen export by recruiting and spatially organizing COPII, tethers and membranes. Elife. https://doi.org/10. 7554/eLife. 32723

Raykhel I, Alanen H, Salo K, Jurvansuu J, Nguyen VD, Latva-Ranta M, Ruddock L (2007) A molecular specificity code for the three mammalian KDEL receptors. J Cell Biol 179:1193-1204. https:// doi.org/10.1083/jcb.200705180

Ríos-Barrera LD, Sigurbjörnsdóttir S, Baer M, Leptin M (2017) Dual function for Tango1 in secretion of bulky cargo and in ER-Golgi morphology. Proc Natl Acad Sci USA 114:E10389-e10398. https://doi.org/10.1073/pnas.1711408114

Rogers MJ, Mönkkönen J, Munoz MA (2020) Molecular mechanisms of action of bisphosphonates and new insights into their effects outside the skeleton. Bone 139:115493. https://doi.org/10.1016/j. bone.2020.115493

Rush ET, Caldwell KS, Kreikemeier RM, Lutz RE, Esposito PW (2014) Osteogenesis imperfecta caused by PPIB mutation with severe phenotype and congenital hearing loss. J Pediatr Genet 3:29-34

Saito K, Yamashiro K, Ichikawa Y, Erlmann P, Kontani K, Malhotra V, Katada T (2011) cTAGE5 mediates collagen secretion through interaction with TANGO1 at endoplasmic reticulum exit sites. Mol Biol Cell 22:2301-2308. https://doi.org/10.1091/mbc. E11-02-0143

Satoh M, Hirayoshi K, Yokota S, Hosokawa N, Nagata K (1996) Intracellular interaction of collagen-specific stress protein HSP47 with newly synthesized procollagen. J Cell Biol 133:469-483. https://doi.org/10.1083/jcb.133.2.469

Schumacher MA, Mizuno K, Bächinger HP (2006) The crystal structure of a collagen-like polypeptide with 3(S)-hydroxyproline residues in the Xaa position forms a standard $7 / 2$ collagen triple helix. J Biol Chem 281:27566-27574. https://doi.org/10.1074/ jbc.M602797200

Schwarz K, Iolascon A, Verissimo F, Trede NS, Horsley W, Chen W, Paw BH, Hopfner KP, Holzmann K, Russo R, Esposito MR, Spano D, De Falco L, Heinrich K, Joggerst B, Rojewski MT, Perrotta S, Denecke J, Pannicke U, Delaunay J, Pepperkok R, Heimpel H (2009) Mutations affecting the secretory COPII coat component SEC23B cause congenital dyserythropoietic anemia type II. Nat Genet 41:936-940. https://doi.org/10.1038/ng.405

Schwarze U, Cundy T, Pyott S, Christiansen H, Hegde M, Bank R, Pals G, Ankala A, Conneely K, Seaver L, Yandow S, Raney E, Babovic-Vuksanovic D, Stoler J, Ben-Neriah Z, Segel R, Lieberman S, Siderius L, Al-Aqeel A, Hannibal M, Hudgins L, McPherson E, Clemens M, Sussman M, Steiner R, Mahan J, Smith R, 
Anyane-Yeboa K, Wynn J, Chong K, Uster T, Aftimos S, Sutton V, Davis E, Kim L, Weis M, Eyre D, Byers P (2013) Mutations in FKBP10, which result in Bruck syndrome and recessive forms of osteogenesis imperfecta, inhibit the hydroxylation of telopeptide lysines in bone collagen. Hum Mol Genet. https://doi.org/ $10.1093 / \mathrm{hmg} / \mathrm{dds} 371$

Segarra NG, Ballhausen D, Crawford H, Perreau M, Campos-Xavier B, van Spaendonck-Zwarts K, Vermeer C, Russo M, Zambelli PY, Stevenson B, Royer-Bertrand B, Rivolta C, Candotti F, Unger S, Munier FL, Superti-Furga A, Bonafé L (2015) NBAS mutations cause a multisystem disorder involving bone, connective tissue, liver, immune system, and retina. Am J Med Genet Part A 167:2902-2912. https://doi.org/10.1002/ajmg.a.37338

Setijowati ED, van Dijk FS, Cobben JM, van Rijn RR, Sistermans EA, Faradz SMH, Kawiyana S, Pals G (2012) A novel homozygous 5 bp deletion in FKBP10 causes clinically Bruck syndrome in an Indonesian patient. Eur J Med Genet 55:17-21. https://doi.org/ 10.1016/j.ejmg.2011.10.002

Shibuya A, Margulis N, Christiano R, Walther TC, Barlowe C (2015) The Erv41-Erv46 complex serves as a retrograde receptor to retrieve escaped ER proteins. J Cell Biol 208:197-209. https:// doi.org/10.1083/jcb.201408024

Sillence DO, Senn A, Danks DM (1979) Genetic heterogeneity in osteogenesis imperfecta. J Med Genet 16:101-116. https://doi. org/10.1136/jmg.16.2.101

Stefanovic B, Stefanovic L, Schnabl B, Bataller R, Brenner DA (2004) TRAM2 protein interacts with endoplasmic reticulum $\mathrm{Ca}^{2+}$ pump Serca2b and is necessary for collagen type I synthesis. Mol Cell Biol 24:1758-1768. https://doi.org/10.1128/mcb.24.4.17581768.2004

Stephens DJ (2012) Cell biology: collagen secretion explained. Nature 482:474-475. https://doi.org/10.1038/482474a

Symoens S, Malfait F, D'Hondt S, Callewaert B, Dheedene A, Steyaert W, Bächinger HP, De Paepe A, Kayserili H, Coucke PJ (2013) Deficiency for the ER-stress transducer OASIS causes severe recessive osteogenesis imperfecta in humans. Orphanet J Rare Dis 8:154. https://doi.org/10.1186/1750-1172-8-154

Syx D, Ishikawa Y, Gebauer J, Boudko SP, Guillemyn B, Van Damme T, D'Hondt S, Symoens S, Nampoothiri S, Gould DB, Baumann U, Bächinger HP, Malfait F (2021) Aberrant binding of mutant HSP47 affects posttranslational modification of type I collagen and leads to osteogenesis imperfecta. PLoS Genet 17:e1009339. https://doi.org/10.1371/journal.pgen.1009339

Takagi M, Ishii T, Barnes AM, Weis M, Amano N, Tanaka M, Fukuzawa R, Nishimura G, Eyre DR, Marini JC, Hasegawa T (2012) A novel mutation in LEPRE1 that eliminates only the KDEL ER-retrieval sequence causes non-lethal osteogenesis imperfecta. PLoS ONE 7:e36809. https://doi.org/10.1371/journal. pone.0036809

Takaluoma K, Lantto J, Myllyharju J (2007) Lysyl hydroxylase 2 is a specific telopeptide hydroxylase, while all three isoenzymes hydroxylate collagenous sequences. Matrix Biol 26:396-403. https://doi.org/10.1016/j.matbio.2007.01.002

Takeyari S, Kubota T, Ohata Y, Fujiwara M, Kitaoka T, Taga Y, Mizuno K, Ozono K (2020) 4-phenylbutyric acid enhances the mineralization of osteogenesis imperfecta iPSC-derived osteoblasts. J Biol Chem. https://doi.org/10.1074/jbc.RA120.014709

Trychta KA, Bäck S, Henderson MJ, Harvey BK (2018) KDEL receptors are differentially regulated to maintain the ER proteome under calcium deficiency. Cell Rep 25:1829-1840.e6. https:// doi.org/10.1016/j.celrep.2018.10.055

Tsai YC, Weissman AM (2010) The unfolded protein response, degradation from endoplasmic reticulum and cancer. Genes Cancer 1:764-778. https://doi.org/10.1177/1947601910383011
Turecek C, Fratzl-Zelman N, Rumpler M, Buchinger B, Spitzer S, Zoehrer R, Durchschlag E, Klaushofer K, Paschalis EP, Varga F (2008) Collagen cross-linking influences osteoblastic differentiation. Calcif Tissue Int 82:392-400. https://doi.org/10.1007/ s00223-008-9136-3

Tzaphlidou M (2001) Measurement of the axial periodicity of collagen fibrils using an image processing method. Micron 32:337-339. https://doi.org/10.1016/s0968-4328(00)00039-1

Uzel MI, Scott IC, Babakhanlou-Chase H, Palamakumbura AH, Pappano WN, Hong HH, Greenspan DS, Trackman PC (2001) Multiple bone morphogenetic protein 1-related mammalian metalloproteinases process pro-lysyl oxidase at the correct physiological site and control lysyl oxidase activation in mouse embryo fibroblast cultures. J Biol Chem 276:22537-22543. https://doi.org/ 10.1074/jbc.M102352200

Van Dijk FS, Sillence DO (2014) Osteogenesis imperfecta: clinical diagnosis, nomenclature and severity assessment. Am J Med Genet 164:1470-1481. https://doi.org/10.1002/ajmg.a.36545

Van Dijk FS, Nesbitt IM, Nikkels PGJ, Dalton A, Bongers EMHF, van de Kamp JM, Hilhorst-Hofstee Y, Den Hollander NS, Lachmeijer AMA, Marcelis CL, Tan-Sindhunata GMB, van Rijn RR, Meijers-Heijboer H, Cobben JM, Pals G (2009a) CRTAP mutations in lethal and severe osteogenesis imperfecta: the importance of combining biochemical and molecular genetic analysis. Eur J Hum Genet 17:1560-1569. https://doi.org/10.1038/ejhg.2009.75

Van Dijk FS, Pals G, Van Rijn RR, Nikkels PGJ, Cobben JM (2010) Classification of osteogenesis imperfecta revisited. Eur J Med Genet 53:1-5. https://doi.org/10.1016/j.ejmg.2009.10.007

van Dijk FS, Nesbitt IM, Zwikstra EH, Nikkels PG, Piersma SR, Fratantoni SA, Jimenez CR, Huizer M, Morsman AC, Cobben JM, van Roij MH, Elting MW, Verbeke JI, Wijnaendts LC, Shaw NJ, Högler W, McKeown C, Sistermans EA, Dalton A, MeijersHeijboer H, Pals G (2009b) PPIB mutations cause severe osteogenesis imperfecta. Am J Hum Genet 85:521-527. https://doi. org/10.1016/j.ajhg.2009.09.001

van Dijk FS, Byers PH, Dalgleish R, Malfait F, Maugeri A, Rohrbach M, Symoens S, Sistermans EA, Pals G (2012) EMQN best practice guidelines for the laboratory diagnosis of osteogenesis imperfecta. Eur J Hum Genet 20:11-19. https://doi.org/10.1038/ ejhg.2011.141

van Dijk FS, Zillikens MC, Micha D, Riessland M, Marcelis CLM, de Die-Smulders CE, Milbradt J, Franken AA, Harsevoort AJ, Lichtenbelt KD, Pruijs HE, Rubio-Gozalbo ME, Zwertbroek R, Moutaouakil Y, Egthuijsen J, Hammerschmidt M, Bijman R, Semeins CM, Bakker AD, Everts V, Klein-Nulend J, CamposObando N, Hofman A, te Meerman GJ, Verkerk AJMH, Uitterlinden AG, Maugeri A, Sistermans EA, Waisfisz Q, Meijers-Heijboer H, Wirth B, Simon MEH, Pals G (2013) PLS3 mutations in X-linked osteoporosis with fractures. N Engl J Med 369:1529-1536. https://doi.org/10.1056/nejmoa1308223

van Dijk FS, Semler O, Etich J, Köhler A, Jimenez-Estrada JA, Bravenboer N, Claeys L, Riesebos E, Gegic S, Piersma SR, Jimenez CR, Waisfisz Q, Flores CL, Nevado J, Harsevoort AJ, Janus GJM, Franken AAM, van der Sar AM, Meijers-Heijboer H, Heath KE, Lapunzina P, Nikkels PGJ, Santen GWE, Nüchel J, Plomann M, Wagener R, Rehberg M, Hoyer-Kuhn H, Eekhoff EMW, Pals G, Mörgelin M, Newstead S, Wilson BT, Ruiz-Perez VL, Maugeri A, Netzer C, Zaucke F, Micha D (2020) Interaction between KDELR2 and HSP47 as a key determinant in osteogenesis imperfecta caused by bi-allelic variants in KDELR2. Am J Hum Genet 107:989-999. https://doi.org/10.1016/j.ajhg.2020.09.009

Volodarsky M, Markus B, Cohen I, Staretz-Chacham O, Flusser H, Landau D, Shelef I, Langer Y, Birk OS (2013) A deletion mutation in TMEM38B associated with autosomal recessive 
osteogenesis imperfecta. Hum Mutat 34:582-586. https://doi. org/10.1002/humu.22274

Wang XH, Su M, Gao F, Xie W, Zeng Y, Li DL, Liu XL, Zhao H, Qin L, Li F, Liu Q, Clarke OB, Lam SM, Shui GH, Hendrickson WA, Chen YH (2019) Structural basis for activity of TRIC counter-ion channels in calcium release. Proc Natl Acad Sci USA 116:42384243. https://doi.org/10.1073/pnas.1817271116

Weinstock M, Leblond CP (1974) Synthesis, migration, and release of precursor collagen by odontoblasts as visualized by radioautography after $(3 \mathrm{H})$ proline administration. J Cell Biol 60:92-127. https://doi.org/10.1083/jcb.60.1.92

Wenger MPE, Bozec L, Horton MA, Mesquida P (2007) Mechanical properties of collagen fibrils. Biophys J 93:1255-1263. https:// doi.org/10.1529/biophysj.106.103192

Widmer C, Gebauer JM, Brunstein E, Rosenbaum S, Zaucke F, Drögemüller C, Leeb T, Baumann U (2012) Molecular basis for the action of the collagen-specific chaperone Hsp47/SERPINH1 and its structure-specific client recognition. Proc Natl Acad Sci USA 109:13243-13247. https://doi.org/10.1073/pnas. 1208072109

Wong MY, Shoulders MD (2019) Targeting defective proteostasis in the collagenopathies. Curr Opin Chem Biol 50:80-88. https:// doi.org/10.1016/j.cbpa.2019.02.021

Wortel IMN, van der Meer LT, Kilberg MS, van Leeuwen FN (2017) Surviving stress: modulation of ATF4-mediated stress responses in normal and malignant cells. Trends Endocrinol Metab 28:794806. https://doi.org/10.1016/j.tem.2017.07.003

Wu Z, Newstead S, Biggin PC (2020) The KDEL trafficking receptor exploits $\mathrm{pH}$ to tune the strength of an unusual short hydrogen bond. Sci Rep 10:16903. https://doi.org/10.1038/ s41598-020-73906-3

Xiao J, Cheng H, Silva T, Baum J, Brodsky B (2011) Osteogenesis imperfecta missense mutations in collagen: structural consequences of a glycine to alanine replacement at a highly charged site. Biochemistry 50:10771-10780. https://doi.org/10.1021/ bi201476a

Yamamura I, Hirata H, Hosokawa N, Nagata K (1998) Transcriptional activation of the mouse HSP47 gene in mouse osteoblast
MC3T3-E1 cells by TGF-beta 1. Biochem Biophys Res Commun 244:68-74. https://doi.org/10.1006/bbrc.1998.8216

Yang H, Niemeijer M, van de Water B, Beltman JB (2020) ATF6 is a critical determinant of $\mathrm{CHOP}$ dynamics during the unfolded protein response. iScience 23:100860. https://doi.org/10.1016/j. isci.2020.100860

Yehia L, Niazi F, Ni Y, Ngeow J, Sankunny M, Liu Z, Wei W, Mester JL, Keri RA, Zhang B, Eng C (2015) Germline heterozygous variants in SEC23B are associated with Cowden syndrome and enriched in apparently sporadic thyroid cancer. Am J Hum Genet 97:661-676. https://doi.org/10.1016/j.ajhg.2015.10.001

Yeowell HN, Steinmann B (1993) PLOD1-related kyphoscoliotic Ehlers-Danlos syndrome. In: Adam MP, Ardinger HH, Pagon RA, Wallace SE, Bean LJH, Mirzaa G, Amemiya A (eds) GeneReviews(®). University of Washington, Seattle

Yuan L, Kenny SJ, Hemmati J, Xu K, Schekman R (2018) TANGO1 and SEC12 are copackaged with procollagen I to facilitate the generation of large COPII carriers. Proc Natl Acad Sci USA 115:E12255-e12264. https://doi.org/10.1073/pnas.1814810115

Zhou P, Liu Y, Lv F, Nie M, Jiang Y, Wang O, Xia W, Xing X, Li M (2014) Novel mutations in FKBP10 and PLOD2 cause rare bruck syndrome in Chinese patients. PLoS ONE 9:e107594. https://doi. org/10.1371/journal.pone.0107594

Zhytnik L, Maasalu K, Pashenko A, Khmyzov S, Reimann E, Prans E, Kõks S, Märtson A (2019) COL1A1/2 pathogenic variants and phenotype characteristics in Ukrainian osteogenesis imperfecta patients. Front Genet 10:722-722. https://doi.org/10.3389/fgene. 2019.00722

Zhytnik L, Maasalu K, Reimand T, Duy BH, Kõks S, Märtson A (2020) Inter- and intrafamilial phenotypic variability in individuals with collagen-related osteogenesis imperfecta. Clin Transl Sci 13:960-971. https://doi.org/10.1111/cts.12783

Publisher's Note Springer Nature remains neutral with regard to jurisdictional claims in published maps and institutional affiliations. 